\title{
The Canada-China FIPPA: Its Uniqueness and Non-Reciprocity
}

Gus Van Harten

Osgoode Hall Law School of York University, gvanharten@osgoode.yorku.ca

Source Publication:

Canadian Yearbook of International Law

Follow this and additional works at: https://digitalcommons.osgoode.yorku.ca/scholarly_works

Part of the International Trade Law Commons

\section{Repository Citation}

Van Harten, Gus, "The Canada-China FIPPA: Its Uniqueness and Non-Reciprocity" (2014). Articles \& Book Chapters. 2495.

https://digitalcommons.osgoode.yorku.ca/scholarly_works/2495

This Article is brought to you for free and open access by the Faculty Scholarship at Osgoode Digital Commons. It has been accepted for inclusion in Articles \& Book Chapters by an authorized administrator of Osgoode Digital Commons. 


\title{
The Canada-China FIPPA: Its uniqueness and non-reciprocity
}

\author{
Gus Van Harten
}

March 2014

[O]ur China FIPPA stuck to the model, the model FIPPA.... This is a perfect example of... a family of investment agreements that Canada has had in place since 1994_in terms of FIPPAs or... investment chapters of free trade agreements. So there is no departure from our past practice in that regard....

\section{Introduction}

The Canada-China Foreign Investment Promotion and Protection Agreement (the China FIPPA) is one of three major trade or investment treaties now pursued by the federal government. ${ }^{2}$ It is also the first treaty, for which an official text is public, since the North American Free Trade Agreement (NAFTA) that would subject all legislatures, governments, and courts in Canada to investorstate arbitration (ISA) in relation to substantial foreign direct investment (FDI) stocks in Canada. ${ }^{3}$ Ratification of the China FIPPA -

\footnotetext{
${ }^{1}$ Hupacasath First Nation v Minister of Foreign Affairs of Canada and Attorney General of Canada, Federal Court Case No T-153-13, CrossExamination on Affidavit of Vernon John MacKay (3 April 2013) at 9 (emphasis added).

${ }^{2}$ Agreement Between the Government of Canada and the Government of the People's Republic of China for the Promotion and Reciprocal Protection of Investments, Canada and China, 9 September 2012, not in force [the China FIPPA]. On the reported delay in ratification by Canada, see Shawn McCarthy, "Pressure mounts with Tories ready to ratify China trade deal by Thursday” The Globe and Mail (30 October 2012); Susana Mas, "Delayed China trade deal reflects Tory dissent, NDP says” CBC News (22 April 2013). Notably, the UN Commission on Trade and Development (UNCTAD) listed the treaty as having entered into force on 7 February 2013 based on a report from China that the treaty entered into force on that date. Because Canada had not ratified the FIPPA by that time, it is assumed that the relevant date may refer to the date of China's ratification of the FIPPA. UNCTAD, “Full List of Bilateral Investment Agreements concluded [by China], 1 June 2013”, available online: http://unctad.org/Sections/dite_pcbb/docs/bits_china.pdf (last accessed 28 January 2014) [after the author's communications with UNCTAD on this issue, the UNCTAD document was revised and now indicates that the FIPPA is not in force].

${ }^{3}$ North American Free Trade Agreement, Canada, Mexico, and U.S.A., 17 December 1992, 32 ILM 296 and 605, entered into force 1 January 1994 [NAFTA].
} 
along with two other proposed trade agreements ${ }^{4}$ - would make Canada the most ISA-constrained country among Western developed countries by far based on the scope of ISA coverage of inward FDI in Canada. ${ }^{5}$ Potential ratification of the China FIPPA is thus an important policy choice that will affect future decision-makers for the long-term. ${ }^{6}$

In this article, the China FIPPA is examined in the context of other trade and investment treaties that provide for ISA. Its text is compared especially to Canada's model FIPPA, other FIPPAs, and trade agreements - including NAFTA - that provide for ISA. ${ }^{7}$ The purpose is to highlight variations in the China FIPPA relative to other relevant treaties of Canada. This sets the stage for an evaluation of the FIPPA's novelty and non-reciprocity - in favour of China - in legal terms and, more tentatively, in its economic context. In summary, it is demonstrated that the China FIPPA is de jure non-reciprocal, and uniquely so, ${ }^{8}$ because it:

- allows a general right of market access by Chinese investors to Canada but not by Canadian investors to China;

- excludes from the treaty's dispute settlement mechanisms, including ISA, decisions on investment screening by sub-national governments in China but not in Canada; and

\footnotetext{
${ }^{4}$ These are the Canada-EU Comprehensive Economic and Trade Agreement (CETA) and the Trans-Pacific Partnership (TPP).

${ }^{5}$ That is, a larger share of FDI stocks in Canada compared to the U.S., Western Europe, and Australia would be covered by ISA. Infra note 176.

${ }^{6}$ Infra note 168.

${ }^{7}$ Canada has concluded five trade agreements including NAFTA that provide for ISA and has concluded 25 FIPPAs (i.e. bilateral investment treaties (BITs)) all of which provide for ISA. The texts of Canada's treaties are available online: http://www.international.gc.ca/trade-agreementsaccords-commerciaux/agr-acc/fipa-apie/index.aspx?lang=eng (last accessed 27 January 2014). See also the Annexes of this article.

${ }^{8}$ By its non-reciprocity on these aspects, the China FIPPA differs from Canada's model FIPPA (infra note 26) and all of Canada's FIPPAs and trade agreements that provide for ISA.
} 
- excludes from the treaty's dispute settlement mechanisms, including ISA, decisions on investment screening in China which, in Canada, would remain subject under the FIPPA to thresholds and other limitations in the Investment Canada Act. ${ }^{9}$

It is explained further that the FIPPA appears de jure non-reciprocal, due to the relatively extensive liberalization of the Canadian economy as compared to the Chinese economy, ${ }^{10}$ because the FIPPA excludes from the treaty's national treatment obligation all existing measures that discriminate against foreign investors and because the FIPPA locks in this un-level feature of the existing playing field between Canada and China.

More broadly, it is highlighted that the FIPPA varies from Canada's usual treaty practice in important ways because it:

- allows expressly a temporal "reach-back" on most-favoured-nation (MFN) treatment such that the scope of MFN treatment is extended to post-1993 investment treaties, thus undermining Canada's post-2001 treaty language that aims to limit various FIPPA provisions in order to re-balance principles of investor protection and regulatory flexibility; ${ }^{11}$

- removes reservations from the FIPPA's obligations on performance requirements, including an aboriginal rights reservation that is included in all of Canada's 25 FIPPAs and trade agreements which contain obligations on performance requirements; ${ }^{12}$

\footnotetext{
${ }^{9}$ Investment Canada Act, RSC 1985, c 28 (1 ${ }^{\text {st }}$ Supp).

${ }^{10}$ Infra notes 105-7.

${ }^{11}$ This distinguishes the China FIPPA from Canada's model FIPPA, NAFTA, Canada's other trade agreements that provide for ISA, and all but two of 25 FIPPAs; the two FIPPAs also do not raise comparable issues for Canada about regulatory flexibility because they apply to little inward FDI). Infra note 174 (Table 2).

${ }^{12}$ This includes all of Canada’s FIPPAs and trade agreements that provide for ISA and prohibit performance requirements. Infra note 147-8.
} 
- scales back Canada’s well-established position on transparency in ISA by setting up a presumption that all documents, other than awards, filed or issued in ISA proceedings are confidential unless the respondent state decides to make them public; ${ }^{13}$ and

- has a minimum lifespan of 31 years, including a 16-year effective minimum term and 15-year survival clause, that goes beyond all but one other treaty concluded by Canada that provides for ISA. ${ }^{14}$

Finally, it is suggested that the FIPPA is apparently de facto non-reciprocal because it provides for robust substantive investor protection and ISA, with corresponding fiscal risks and regulatory constraints for states in their role as capital-importers, in a context where Chinese FDI stocks in Canada exceed Canadian FDI stocks in China by factor of about 3 to $1{ }^{15}$

The commentary in this article is specific to the China FIPPA and focuses on the FIPPA text in its legal and economic context. The analysis responds partly to claims by federal government officials, among others, that the China FIPPA is unremarkable because it continues Canada's past practice. ${ }^{16}$ Other questions about the FIPPA and its cost-benefit implications are raised in the conclusion of the article with a suggestion that the FIPPA, due to its significance, uniqueness, and long-term irreversibility, should be subject to a comprehensive independent review before a decision is taken by the federal government on whether to ratify the FIPPA.

\footnotetext{
${ }^{13}$ This distinguishes the China FIPPA from Canada's model FIPPA, NAFTA, and all 10 of Canada's post-2001 FIPPAs and trade agreements that provide for ISA (i.e. all relevant treaties since the federal government responded to emergent issues of ISA confidentiality under NAFTA).

${ }^{14}$ Infra note 168.

${ }^{15}$ Infra note 174 (Table 2). This distinguishes the China FIPPA from all of Canada's relevant treaties except NAFTA.

${ }^{16}$ Supra note 1.
} 
DRAFT/ Accepted for publication: Canadian Yearbook of International Law/ Annuaire Canadien de droit international (2014)

\section{General Context}

\section{A. Historical aspects}

The China FIPPA is a bilateral investment treaty (BIT). BITs that provide for ISA date from the late 1960 s. ${ }^{17}$ At this time, major Western European capital-exporting states began to develop model investment treaties in their relations with former colonies and developing states. The model was extended to relations with former East Bloc states and to relations among many transition and developing states. Around 1980, the U.S. developed its model investment treaty and from about 1990 the number of BITs providing for ISA expanded rapidly; ISA also began to be incorporated into trade agreements such as NAFTA. The China FIPPA is consistent with the general approach to BITs since this post-1990 expansion. Speaking generally, Canada adopted this general approach, based especially on the U.S. approach to BITs, after NAFTA entered into force in 1994 whereas China did so around $2000 .^{18}$ In particular, the China FIPPA is consistent with a muscular version of ISA based on these elements:

- Investors can bring claims against states (but not vice versa) in relation to most or all aspects of the treaty rather than a limited class of potential disputes, such as disputes over the amount of compensation to be paid in the event of an expropriation.

\footnotetext{
${ }^{17}$ Andrew Newcombe and Lluís Paradell, Law and Practice of Investment Treaties (Alphen aan den Rijn: Kluwer Law International, 2009) at 449.

${ }^{18}$ Axel Berger, China and the Global Governance of Foreign Direct Investment (Bonn: German Development Institute, 2008) at 21-2; Monica C.E. Heymann, "International Law and the Settlement of Investment Disputes Relating to China” (2008) 11:3 JIEL 507 at 515-16; Gordon Smith, “Chinese Bilateral Investment Treaties: Restrictions on International Arbitration” (2010) 76 Arbitration 58 at 58-9.
} 
- Investors can bring claims in forums where voting power is concentrated in the hands of the major capital-exporting states, ${ }^{19}$ here pursuant to the International Centre for Settlement of Investment Disputes (ICSID) Rules, the ICSID Additional Facility, and the UN Commission on International Trade Law (UNCITRAL) Rules, which locate significant powers over the arbitration process, including default arbitrator appointment powers, at the World Bank or Permanent Court of Arbitration. ${ }^{20}$

- Investors can bring claims without having to exhaust domestic remedies in the host state regardless of whether those remedies are capable of delivering justice.

- Investors are not precluded, according to most investment treaty awards, ${ }^{21}$ from submitting contractual disputes with the host state or a related entity to the treaty's arbitration mechanism even if the contract calls for the resolution of disputes exclusively in another forum.

- Arbitrators can discipline states based on broadly-worded standards including protections from treatment that is not fair and equitable, that does not ensure full protection and security, that is discriminatory in relation to domestic or third-state investors, or that is an expropriation or tantamount to expropriation.

\footnotetext{
${ }^{19}$ Gus Van Harten, “Investment Treaty Arbitration, Procedural Fairness, and the Rule of Law” in Stephan W Schill, ed, International Investment Law and Comparative Public Law (Oxford: OUP, 2010) at 645-8.

${ }^{20}$ International Centre for Settlement of Investment Disputes (ICSID), Rules of Procedure for Arbitration Proceedings, revised 26 September 1984 and 1 January 2003 (original rules 1968), reprinted in Convention, Regulations and Rules (Washington: ICSID, 2003) [ICSID Rules]; ICSID, Rules Governing the Additional Facility for the Administration of Proceedings by the Secretariat of the International Centre for Settlement of Investment Disputes, revised 1 January 2003 (original rules 1978), 1 ICSID Rep 213 [ICSID Additional Facility Rules]; UN Commission on International Trade Law (UNCITRAL), Arbitration Rules of the United Nations Commission on International Trade Law, UN GA Res 31/98, UN GAOR, 31st Sess, Supp No 17, UN Doc A/31/17, c V, s C (1976) [UNCITRAL Rules].

${ }^{21}$ Gus Van Harten, Sovereign Choices and Sovereign Constraints: Judicial Restraint in Investment Treaty Arbitration (Oxford: OUP, 2013) at 135-47.
} 
- Arbitrators can review the conduct of virtually any branch or entity of the state including at the sub-national level.

- Arbitrators can award monetary damages, as opposed to conventional public law remedies, ${ }^{22}$ as a primary remedy where the state is found to have violated its treaty obligations.

- Foreign states can enforce an arbitration award against assets if the losing state based on enforcement provisions of the ICSID Convention, the New York Convention, and/ or the Panama Convention. ${ }^{23}$

These elements of the FIPPA are common in BITs and trade agreements that provide for ISA. On the other hand, the China FIPPA does not reflect other elements of a muscular version of ISA as follows.

- Foreign investors can in some circumstances be blocked from forum-shopping - i.e. from assuming the status of an investor covered by the FIPPA by establishing an intermediary company in the host state - due to the FIPPA's flexible denial-ofbenefits clause. $^{24}$

\footnotetext{
${ }^{22}$ Anne van Aaken, "Primary and Secondary Remedies in International Investment Law and National State Liability: A Functional and Comparative View" in Stephan W. Schill, ed, International Investment Law and Comparative Public Law (Oxford: OUP, 2010) at 723 and 72530.

${ }^{23}$ Convention on the Settlement of Investment Disputes Between States and Nationals of Other States, 18 March 1965, 4 ILM 524, entered into force 14 Oct 1966 [the ICSID Convention]; United Nations Convention on the Recognition and Enforcement of Foreign Arbitral Awards, 10 June 1958, 330 UNTS 3, entered into force 7 June 1959 [the New York Convention]; Inter-American Convention on International Commercial Arbitration, 30 January 1975, 14 ILM 336 [the Panama Convention].

${ }^{24}$ China FIPPA, supra note 2, Article 16(2) and (3). Rachel Thorn and Jennifer Doucleff, "Disregarding the Corporate Veil and Denial of Benefits Clause: Testing Treaty Language and the Concept of 'Investor'” in Michael Waibel et al, eds, The Backlash Against Investment Arbitration (Alphen aan den Rijn: Kluwer Law International, 2010) 3 at 25-6.
} 
- Investors are not entitled to pre-establishment national treatment although they are entitled to pre-establishment MFN treatment.

- Investors are precluded expressly from accessing, based on MFN treatment, more favourable dispute settlement provisions in other investment treaties, as otherwise permitted by about half of investment treaty tribunals that have opined on the issue. ${ }^{25}$

These aspects of the China FIPPA are significant even if they do not alter the FIPPA's position as a typical muscular BIT. As such, the FIPPA like many treaties gives a special status to foreign investors in the form of (a) substantive legal protections not enjoyed by other private parties including domestic competitors and (b) access to ISA including relief from the customary duty to exhaust reasonablyavailable domestic remedies before an international claim can be brought.

\section{B. Legal aspects}

Among treaties that provide for ISA, the China FIPPA tracks most closely the structure of the NAFTA investment chapter which was based originally on the U.S. prototype BIT and was adopted by Canada in many post-NAFTA FIPPAs and in Canada’s model FIPPA of 2004. ${ }^{26}$ Thus, the FIPPA may be said to fall within a North American species of BITs, albeit with important variations discussed in the next section of this article. In this section, a general overview of the FIPPA is provided.

\footnotetext{
${ }^{25}$ Gus Van Harten, “Arbitrator Behaviour in Asymmetrical Adjudication: An Empirical Study of Investment Treaty Arbitration” (2012) 50 OHLJ 211 at 228 and 237-8.

${ }^{26}$ Canada, “Agreement Between Canada and [other country] for the Promotion and Protection of Investments” (2004) [Canada’s model FIPPA], available online: http://italaw.com/documents/Canadian2004-FIPA-model-en.pdf (last accessed 26 January 2014).
} 
The China FIPPA contains a typically broad definition of the concept of investment. The definition extends beyond physical assets like land and buildings and beyond notions of FDI (based on ownership and control of assets) to include other concepts of asset ownership. For example, the FIPPA includes in its definition of investment: resource concession rights, debt instruments (i.e. portfolio investment), intellectual property rights, and "any other tangible or intangible... property and related property rights acquired or used for business purposes”. ${ }^{27}$ Thus, like most treaties that provide for ISA, the FIPPA’s coverage is wide-ranging in its application to economic activities of foreign investors. The question of whether this breadth of application goes beyond comparable concepts in Canadian or other domestic law is beyond the scope of this article. ${ }^{28}$

2. Broad definition of investor, with an important qualification

The FIPPA also has a broad definition of the concept of an investor. The definition includes any natural and corporate person that has foreign Canadian or Chinese nationality and that "seeks to make, is making or has made a covered investment". ${ }^{29}$ On the other hand, the FIPPA constrains forum-shipping by foreign investors by allowing the host state to deny benefits of the FIPPA to Canadian or Chinese investors (as applicable) that are controlled by investors, from a third-state or from the host state itself, that have no substantial business activities in the host state's territory. ${ }^{30}$ This denial-of-benefits clause is more clearly reliable for respondent states

\footnotetext{
${ }^{27}$ China FIPPA, supra note 2, Article 1(1).

${ }^{28}$ e.g. Steven Shrybman, "Submissions to Standing Committee on International Trade Re: AbitibiBowater NAFTA Claim Settlement”, Submission to the House of Commons International Trade Committee (8 March 2011), available online: http://www.canadians.org/sites/default/files/Trade/Submissions_AbitibiBowater.pdf (last accessed 26 January 2014).

${ }^{29}$ China FIPPA, supra note 2, Article 1(2) and (10(a)).

${ }^{30}$ Ibid, Article 16(2) and (3).
} 
than are similar provisions in NAFTA and other FIPPAs because the clause allows a host state to deny benefits after ISA proceedings have been initiated, without any express or implied requirement of advance notice or consultation. ${ }^{31}$

\section{Broad application to state measures}

The FIPPA applies broadly to any measures of Canada or China including legislative, executive, or judicial measures of the federal government or a provincial, territorial, or local government or First Nations authority. ${ }^{32}$ This reflects the principle of the state as a unified entity under international law and it is typical of treaties providing for ISA. ${ }^{33}$

4. Inclusion of core substantive standards

Much of the FIPPA's substantive content reflects many other treaties that provide for ISA. ${ }^{34}$ Thus, the FIPPA includes:

(a) a minimum standard of treatment for investors including "fair and equitable treatment" and "full protection and security",35

\footnotetext{
${ }^{31}$ No other relevant treaties of Canada include the express clarification contained in the China FIPPA, supra note 2, Article 18(3), that access to ISA can be denied after the initiation of an ISA claim. Compare NAFTA, supra note 3, Article 1113(2); Canada's model FIPPA, supra note 26, Article 18(2). Thorn and Doucleff, supra note 24 at 25-6. Other treaties concluded by Canada that have more ambiguous denial-of benefits provisions include Canada's FIPPAs with Costa Rica, the Czech Republic, Jordan, Latvia, Peru, Romania, the Slovak Republic, and Tanzania and Canada's trade agreements with Chile, Colombia, Panama, and Peru. Also, 17 of Canada's FIPPAs, the latest of which (with Croatia) entered into force in 2001, do not have any denial-of-benefits provisions. See Annex I.

${ }^{32}$ China FIPPA, supra note 2, Article 2(1); see also Article 2(2).

${ }^{33}$ e.g. International Law Commission (ILC), Responsibility of States for Internationally Wrongful Acts, 2001, Annex to UNGA Res 56/83 (2001), Article 4(1).

${ }^{34}$ The China FIPPA also excludes, whether entirely or from ISA only, provisions on monopolies and regulatory transparency. That said, comparable provisions in other treaties have not figured prominently if at all in actual ISA cases and are apparently non-binding in important respects in Canada's model FIPPA, supra note 26, Articles 8 and 19.

${ }^{35}$ China FIPPA, supra note 2, Article 4(1).
} 
DRAFT/ Accepted for publication: Canadian Yearbook of International Law/ Annuaire Canadien de droit international (2014)

(b) MFN treatment and national treatment at the post-establishment stage of an investment, ${ }^{36}$

(c) protections from direct or indirect expropriation including a requirement for market-based compensation, ${ }^{37}$

(d) free transfers of capital, ${ }^{38}$

(e) MFN treatment at the pre-establishment stage of an investment, ${ }^{39}$

(f) a prohibition on performance requirements, ${ }^{40}$ and

(g) requirements on the make-up of senior management and boards of directors and on entry of key personnel. ${ }^{41}$

Items (a) through (d) above reflect the great majority of BITs whereas items (e) to (g) reflect mainly the North American approach.

\footnotetext{
${ }^{36}$ Ibid, Article 5(1) and (2) and Article 6(1) and (2). See also Article 11.

${ }^{37}$ Ibid, Article 10.

${ }^{38}$ Ibid, Article 12.

${ }^{39}$ Ibid, Article 5(1) and (2).

${ }^{40}$ Ibid, Article 9.

${ }^{41}$ Ibid, Article 7(1), (2), and (3).
} 
5. Limiting language for substantive provisions

Consistent also with the North American approach, the FIPPA contains limiting language for some of its substantive provisions. This limiting language applies to the FIPPA's provisions for a minimum standard of treatment and for MFN treatment, reflecting the approach in the NAFTA states' clarification in 2001 of the equivalent NAFTA provisions, ${ }^{42}$ and to the FIPPA's expropriation clause reflecting the post-2001 practice of the U.S. and Canada. In particular, on the minimum standard of treatment, the FIPPA provides that (a) concepts of fair and equitable treatment and full protection and security do not require treatment beyond that required by the international law minimum standard of treatment as evidenced by general state practice accepted as law and (b) a state’s breach of another standard or treaty does not constitute a breach of the FIPPA's minimum standard. ${ }^{43}$ In addition, the FIPPA's MFN treatment clause provides expressly that MFN treatment does not extend to aspects of dispute resolution mechanisms in other treaties. ${ }^{44}$ Finally, the FIPPA seeks to clarify and limit the concept of indirect expropriation in ways derived mainly from U.S. takings law. ${ }^{45}$

These limiting provisions reflect a post-2001 North American approach to the relevant substantive standards. That said, as for any treaty that provides for ISA, the limiting language is subject to interpretation by investment treaty arbitrators and, in many cases under other treaties, arbitrators have adopted an expansive approach to ambiguous treaty language. ${ }^{46}$ This appears especially important in the case of the China FIPPA due to its approach to MFN treatment, as discussed below.

\footnotetext{
${ }^{42}$ NAFTA Free Trade Commission, Notes of Interpretation of Certain Chapter 11 Provisions (31 July 2001), 13(6) World Trade and Arb Mat 139, Article B(1).

${ }^{43}$ China FIPPA, supra note 2, Article 4(2) and (3).

${ }^{44}$ Ibid, Article 5(3).

${ }^{45}$ Ibid, Annex B.10; Andrea J. Menaker, "Benefiting From Experience: Developments in the United States’ Most Recent Investment Agreements” (2005) 12 UC Davis J Int'l L \& Pol 121 at 124 (note 8).

${ }^{46}$ Van Harten, supra note 25 at 225-8 and 237-40.
} 
6. Other limitations on substantive standards of investor protection

The China FIPPA includes other limiting aspects that reflect Canada’s FIPPA practice. In particular, the FIPPA has a clause especially relevant to its allowance for free transfers of capital ${ }^{47}$ - that may assist to protect a host state's financial stability, although the version of this clause in the China FIPPA appears narrower than in most of Canada's other relevant treaties. ${ }^{48}$ The FIPPA also contains a partial carve-out for tax measures ${ }^{49}$ and its provisions on non-discrimination are subject to exceptions for existing discriminatory measures and for procurement, subsidies, and other matters. ${ }^{50}$ These features - encompassing exceptions both from substantive standards and from dispute settlement provisions - are typical of Canada's treaties.

In addition, the China FIPPA contains general exceptions for health, environmental, and conservation measures reflecting Canada's post-1993 treaty practice other than in NAFTA and one other trade agreement that provides for ISA. ${ }^{51}$ The general exceptions state that the FIPPA is not to be construed so as "to prevent a Contracting Party from adopting or maintaining measures, including environmental measures” that are (a) necessary to ensure compliance with laws and regulations that are not themselves inconsistent with the FIPPA, (b) necessary to protect human, animal or plant life or health, or (c) relating to the conservation of living or non-living exhaustible natural resources, under certain conditions. ${ }^{52}$

\footnotetext{
${ }^{47}$ China FIPPA, supra note 2, Article 12(1).

${ }^{48}$ Ibid, Article 12(4). Compare Canada’s model FIPPA, supra note 26, Article 14(6). Only Canada’s four pre-1994 FIPPAs do not contain the relevant clause.

${ }^{49}$ China FIPPA, supra note 2, Article 14(1), (4), and (5). The carve-out is partial because it does not apply to tax measures that lead to expropriation claims where the states parties do not agree, after the filing of the claim, that the relevant measure is not an expropriation.

${ }^{50}$ Ibid, Article 8.

${ }^{51}$ Canada's four pre-1994 FIPPAs do not contain these general exceptions; NAFTA and Canada's trade agreement with Chile limit the exceptions to certain performance requirements; e.g. NAFTA, supra note 3, Article 1106(6). See Annex I.

${ }^{52}$ China FIPPA, supra note 2, Article 33(2). The FIPPA, Article 33(1), also has a general exception for cultural industries that is similar to Canada's other FIPPAs and trade agreements.
} 
These exceptions provide protection for various areas of government decision-making although the degree of protection is uncertain for several reasons. First, necessity requirements have been approached strictly by most of the investment treaty tribunals that have dealt with them in the comparable context of emergency economic measures. ${ }^{53}$ Second, the exceptions are subject to other conditional language derived from the chapeau of Article XX of the General Agreement on Trade and Tariffs (GATT) which provides additional discretion to arbitrators to limit the protection afforded by the exceptions. ${ }^{54}$ Third, the exceptions may be diluted by the FIPPA's approach to MFN treatment as discussed below. ${ }^{55}$ Fourth, and perhaps most importantly, arbitrators may conclude that a monetary award against a state in the context of ISA does not "prevent" the state from adopting a measure and, in turn, that none of the exceptions would excuse a state from any FIPPA obligation to compensate investors who experience loss due to the state’s actions in areas of health, environment, and conservation. Overall, while the exceptions may safeguard some state conduct from treaty liability, they remain untested in ISA and are subject to important qualifications. ${ }^{56}$

\footnotetext{
53 e.g. CMS v Argentina (2005), 44 ILM 1205 at paras 316-17, 329, and 331 (ICSID); Enron v Argentina (2007), ICSID Case No ARB/01/3 at paras 303-9 and 311-13 (ICSID); Sempra v Argentina (2007), 20 World Trade and Arb Mat 117 at paras 347-55 and 373-4 (ICSID); National Grid $v$ Argentina (3 November 2008), available online: http://italaw.com/sites/default/files/case-documents/ita0555.pdf (last accessed 26 January 2014) at paras. 257-62 (UNCITRAL); Suez \& InterAgua v Argentina (2010), ICSID Case No ARB/03/17 at paras 235-43 (ICSID); Total v Argentina (2010), ICSID Case No ARB/04/01 at paras 221-4, 345, and 483-4 (ICSID); EDF v Argentina (2012), ICSID Case No ARB/03/23 at paras 1171-3 (ICSID). Contrast LG\&E v Argentina (2006), 46 ILM 40 at paras 228-61 (ICSID); Continental Casualty v Argentina (2008), 21 World Trade and Arb Mat 181 at paras 173-81, 192-210, and 227-36 (ICSID).

${ }^{54}$ China FIPPA, supra note 2, Article 33(2).

${ }^{55}$ This would depend among other things on whether the language defining the general exception in any post-1993 FIPPAs was weaker than that in the China FIPPA; infra note 113.

${ }^{56}$ See also Andrew Newcombe, “Canada’s New Model Foreign Investment Protection Agreement” (August 2004) at 4-5, available online: http://italaw.com/documents/CanadianFIPA.pdf (last accessed 26 January 2014).
} 


\section{Institutional structure}

The China FIPPA's institutional structure is consistent with the general approach in Canada's model FIPPA, NAFTA, and other relevant treaties of Canada and many other investment treaties. The FIPPA provides for state-state arbitration; ${ }^{57}$ investor-state arbitration; ${ }^{58}$ availability of the ICSID Rules, ICSID Additional Facility Rules, and UNCITRAL Rules for ISA, ${ }^{59}$ the ICSID Secretary General as default appointing authority, ${ }^{60}$ and binding interpretations by the state parties. ${ }^{61}$ Its provisions on governing law, ${ }^{62}$ public access, ${ }^{63}$ finality and enforcement of awards, ${ }^{64}$ and entry into force ${ }^{65}$ also track the usual approach. However, there are some variations in the FIPPA's institutional structure. Perhaps the most important, as discussed below, are the FIPPA's dilution of requirements for ISA transparency and its lengthy minimum lifespan. ${ }^{66}$

\section{Uniqueness and non-reciprocity}

For Canada, the negotiation of the China FIPPA presumably called for more concessions than usual due to China's size and bargaining power relative to the other treaty partners of Canada. It is therefore noteworthy that the apparent starting point for negotiation of the China FIPPA was Canada’s model FIPPA. That said, it is also clear that important variations were accepted by

\footnotetext{
${ }^{57}$ China FIPPA, supra note 2, Article 15.

58 Ibid, especially Articles 20 and 22.

${ }^{59}$ Ibid, Article 22(1).

${ }^{60}$ Ibid, Article 24(5).

${ }^{61}$ Ibid, Article 18(2).

62 Ibid, Article 30.

${ }^{63}$ Ibid, Article 28.

${ }^{64}$ Ibid, Article 32.

${ }^{65}$ Ibid, Article 35.

${ }^{66}$ Infra notes 161 and 168.
} 
Canada from its usual approach. The most important variations and corresponding non-reciprocal features ${ }^{67}$ in the China FIPPA are evaluated in detail in this section. After this legal analysis, the FIPPA is evaluated further in its immediate economic context of ChinaCanada investment flows.

\section{Non-reciprocity on market access}

Bilateral investment treaties unlike trade agreements do not provide for market access for goods or services. However, many BITs (and trade agreements) do provide for market access by investors and investments. ${ }^{68}$ That is, they require the states parties to allow foreign investors to purchase domestic companies or other assets and thus to make brownfield or greenfield investments in the host state. In this context, market access is often called pre-establishment national treatment because it involves an obligation by the host state not to discriminate between foreign and domestic investors even before a foreign investor has invested in the host state.

Unlike many other BITs, the China FIPPA does not provide for this form of market access. This is because the FIPPA's national treatment obligation does not extend to the pre-establishment stage of a foreign investment; precisely, the obligation does not include the terms “establishment” and “acquisition” alongside “expansion, management, conduct, operation and sale or other disposition” in its description of investment activities to which national treatment applies. ${ }^{69}$ On the other hand, and extraordinarily in light of the

\footnotetext{
${ }^{67}$ Some non-reciprocal aspects of the China FIPPA, such as its provision in Annex C.21(1) that Canadian (but not Chinese) investors must submit a dispute to domestic administrative procedures for four months before bringing a FIPPA claim, were not thought to be important enough to discuss in detail.

${ }^{68}$ This element originates in U.S. BITs and has been adopted in various forms in 21 of Canada's post-NAFTA FIPPAs or trade agreements that provide for ISA. See Annex II of this article.

${ }^{69}$ China FIPPA, supra note 2, Article 6(1) and (2).
} 
FIPPA's more limited national treatment provision, the FIPPA's MFN treatment clause does extend to the pre-establishment stage of a foreign investment. It states: ${ }^{70}$

Each Contracting Party shall accord to investors of the other Contracting Party treatment no less favourable than that it accords, in like circumstances, to investors of a non-Contracting Party with respect to the establishment, acquisition... or other disposition of investments in its territory.

Thus, while the FIPPA does not require non-discrimination in market access between Chinese or Canadian investors (as applicable) and domestic investors, it does provide for non-discrimination in market access between Chinese or Canadian investors and third-state investors in each state.

This structure is unique among treaties concluded by Canada and providing for ISA (indeed, it may be unique among all treaties that provide for ISA). First, the great majority of Canada's treaties provide for pre-establishment national treatment. ${ }^{71}$ Second, none of Canada's treaties that exclude pre-establishment national treatment obligations go on to extend MFN treatment to the preestablishment stage. As discussed below, the upshot of this extraordinary feature of the China FIPPA is to obligate Canada but not $\underline{\text { China }}$ to open its economy to the other state's investors.

The absence of pre-establishment national treatment in the China FIPPA would be less noteworthy, in that it would be a reciprocal element of the treaty, if Canada and China permitted similar levels of market access at present. Yet clearly this is not the case. The

\footnotetext{
${ }^{70}$ Ibid, Article 5(1) and (2).

${ }^{71}$ All of Canada's five trade agreements that provide for ISA and all but four of Canada's 21 FIPPAs since NAFTA extend national treatment to the pre-establishment stage of a foreign investment. In contrast, Canada's four pre-1994 FIPPAs do not extend national treatment to the preestablishment stage. See Annex II of this article.
} 
Canadian economy is significantly more open to foreign investment than the Chinese economy; put differently, Chinese investors are in general able to purchase assets in Canada that Canadian investors would not be able to purchase in China. ${ }^{72}$ As a result, the FIPPA preserves China's asymmetrical freedom to deny market access by Canadian investors; although reciprocal on its face, the FIPPA's implications are in this respect de facto unequal. ${ }^{73}$

Moreover, the China FIPPA establishes de jure non-reciprocity of market access. This is because (a) Canada and China commit to provide market access to investors from the other state only where the other state already provides market access to investors from a third-state ${ }^{74}$ and (b) Canada unlike China ${ }^{75}$ has concluded numerous FIPPAs since $1994^{76}$ in which third-state investors are given expansive rights of market access to Canada. For instance, the Canada-Costa Rica FIPPA states: ${ }^{77}$

\footnotetext{
${ }^{72}$ Cross-Examination on Affidavit of Vernon John MacKay, supra note 1 at 39 (“... over 90 percent of investment entering the Chinese market is subject to review under laws, regulations and rules....”); European Union Chamber of Commerce in China (EUCCC), European Business in China Position Paper 2013/2014 (EUCCC, 2013) 19-20 (“China has used the vast size of its domestic marketplace to protect domestic companies and to place conditionalities on market access for foreign companies.”). Although the relevant rankings do not necessarily define good economic policy, China was listed as the most-restrictive of 55 countries in the OECD’s FDI Regulatory Restrictiveness Index as of September 2013; available online: http://www.oecd.org/daf/inv/ColumnChart-FDI_RR_Index_2013.pdf (last accessed 27 January 2014).

${ }^{73}$ As an aside, the FIPPA preserves the states parties' ability to block takeovers of domestic firms although the relevant provision is also nonreciprocal in important respects; infra note 84 and surrounding discussion.

${ }_{75}^{74}$ China FIPPA, supra note 2, Articles 5 and 8(1)(b).

${ }^{75}$ Stephan W. Schill, “Tearing down the Great Wall: the New Generation of Investment Treaties of the People’s Republic of China” (2007) 15 Cardozo J Int'l and Comp Law 73 at 86.

${ }^{76}$ The China FIPPA does not extend the requirement to provide market access based on MFN treatment to trade agreements or to pre-1994 FIPPAs; China FIPPA, supra note 2, Article 8(1)(a)(i) and (b).

${ }^{77}$ Agreement Between the Government of Canada and the Government of the Republic of Costa Rica for the Promotion and Protection of Investments, Canada and Costa Rica, 18 March 1998, entered into force 29 September 1999 [Costa Rica FIPPA], Article III(1). See also Canada's FIPPAs with Croatia (Article III(1)(b)), Jordan (Article 3(1)), Lebanon (Article III(b)), Peru (Article 3(1)), Tanzania (Article 4(1)), and Uruguay (Article III(b)), available online: http://www.international.gc.ca/trade-agreements-accords-commerciaux/agr-acc/fipa-apie/index.aspx?lang=eng (last accessed 26 January 2014). See also Annex II of this article.
} 
Each Contracting State shall permit establishment of a new business enterprise or acquisition of an existing business enterprise or a share of such enterprise by investors or prospective investors of the other Contracting Party on a basis no less favourable than that which, in like circumstances, it permits such acquisition or establishment by: ... its own investors or prospective investors.

Based on this provision in the Canada-Costa Rica FIPPA, Costa Rican investors obtain a general right to invest in Canada (and vice versa for Canadian investors in Costa Rica). Canada’s commitment in this respect is subject to further exceptions in the Costa Rica FIPPA. ${ }^{78}$ Yet the general provision is for broad market access by the relevant (Costa Rican) third-state investors. Under the China FIPPA, the same right of market access would thus extend to Chinese investors based on the FIPPA's provision for pre-establishment MFN treatment. This derivative right would be subject to the exceptions to the original right in the Costa Rica FIPPA although, as an illustration of its scope, the Costa Rica FIPPA - unlike some other FIPPAs - does not include exceptions for measures in various areas such as atomic energy, air transportation, overseas and coastal shipping, and ownership of real estate. ${ }^{79}$ As a result, in the case of the China FIPPA, Chinese investors would obtain a (non-reciprocal) right of market access to Canada in any areas not exempted expressly in all of Canada's post-1993 FIPPAs that provides for pre-establishment national treatment for the relevant third-state investors. ${ }^{80}$

\footnotetext{
${ }^{78}$ These include exceptions for existing non-conforming measures (so long as they have been laid out by letter from Canada to Costa Rica within two years of the Costa Rica FIPPA's entry into force) and for future measures in areas such as social services, oceanfront land, and government securities. Costa Rica FIPPA, ibid, Annex I (Article II(1)(c) and Article II(2)).

${ }^{79}$ Each of these areas is listed as exempted for the state party other than Canada, but not for Canada, in at least one other post-1993 FIPPA that provides for pre-establishment national treatment; e.g. Agreement Between the Government of Canada and the Government of the Republic of Croatia for the Promotion and Protection of Investments, Canada and Croatia, 3 February 1997, entered into force 30 January 2001, Annex I (Article II(1)(c)); Agreement Between the Government of Canada and the Government of the Lebanese Republic for the Promotion and Protection of Investments, Canada and Lebanon, 11 April 1997 entered into force 19 June 1999, Annex I (Article II(1)(d).

${ }^{80}$ As an aside, it would make no difference that Costa Rica, Croatia, and Jordan do not own substantial assets in Canada for the operation of MFN treatment and market access, as discussed here, in the China FIPPA. It is that the relevant third-state investors receive more favourable treatment at the pre-establishment stage that would entitle Chinese investors to the same rights under the China FIPPA.
} 
On the other hand, China has not committed in any of its BITs to pre-establishment national treatment. ${ }^{81}$ As a result, China would not be obliged under the China FIPPA to allow a derivative right of market access by Canadian investors. Put differently, China has not made any sweetheart deal that must be extended to Canadian investors based on the FIPPA's provision for MFN treatment on market access. If China were in future to give market access to third-state investors, then Canadian investors would be entitled to no less favourable treatment than those third-state investors. Yet this appears to be a big “if” in light of Canada's binding long-term concession on market access by Chinese investors.

By this roundabout path, the China FIPPA provides for market access by Chinese investors to Canada but excludes a right of market access by Canadian investors to China. This lack of reciprocity arises from the interaction between the FIPPA's unique structure - its provision for pre-establishment MFN treatment but not for pre-establishment national treatment - in combination with Canada's other FIPPAs that provide for pre-establishment national treatment. The resulting MFN-derived right of market access by Chinese investors would be subject only to exceptions that were present in all of Canada's post-1993 FIPPAs that provide for pre-establishment national treatment. $^{82}$ This non-reciprocal feature of the FIPPA is an extraordinary concession by Canada against the backdrop of other FIPPAs and BITs in general.

\footnotetext{
${ }^{81}$ Schill, supra note 75. The author reviewed Chinese BITs that entered into force after 2006, a text for which was available via UNCTAD’s database of Investment Instruments Online, in order to confirm Schill's report on this aspect of China's BIT policy. The author's review covered China’s BITs with Colombia, Cuba, France, India, Madagascar, Mexico, Portugal, Romania, Slovakia, South Korea, and Switzerland, none of which were found to provide for pre-establishment national treatment. China's BITs are available online: http://www.unctadxi.org/templates/DocSearch_ 779.aspx (last accessed 27 January 2014).

${ }^{82}$ The right is also subject in the China FIPPA to the federal government's ability to block foreign takeovers under the Investment Canada Act as discussed below.
} 
In the China FIPPA, Canada's federal government would retain the ability to screen Chinese investment in Canada under the Investment Canada Act. ${ }^{83}$ According to the FIPPA, investment screening by Canada and China is excluded from ISA and state-state arbitration: ${ }^{84}$

1. A decision by Canada following a review under the Investment Canada Act, an Act respecting investment in Canada, with respect to whether or not to:

(a) initially approve an investment that is subject to review; or

(b) permit an investment that is subject to national security review;

shall not be subject to the dispute settlement provisions under Article 15 and Part $\mathrm{C}$ of this Agreement.

2. A decision by China following a review under the Laws, Regulations and Rules relating to the regulation of foreign investment, with respect to whether or not to:

(a) initially approve an investment that is subject to review; or

(b) permit an investment that is subject to national security review;

shall not be subject to the dispute settlement provisions under Article 15 and Part $\mathrm{C}$ of this Agreement.

This carve-out preserves the ability of Canada and China to screen (and thus block) a particular foreign investment. However, this carve-out for investment screening, like the FIPPA's provision for market access as discussed above, is non-reciprocal in two important respects.

\footnotetext{
${ }^{83}$ Supra note 9.

${ }^{84}$ China FIPPA, supra note 2, Annex D.34 (emphasis added).
} 
First, unlike Canada's other treaties that provide for ISA, ${ }^{85}$ the carve-out applies to sub-national governments in the case of Canada's treaty partner but not in the case of Canada. Canada has the right to screen Chinese investments under a federal statute, the Investment Canada Act, that is specified expressly in the FIPPA and authorizes the federal government to screen foreign investment. As a result, if a provincial, local, or First Nations government took steps to block or frustrate a foreign takeover, or the federal government did so outside of the Investment Canada Act, then the decision would not fall within the scope of the carve-out and would be subject to Canada's FIPPA obligations on market access. To illustrate, when Quebec took steps to deter a proposed purchase of Rona by Lowe's in 2012, this conduct - understood as a restriction on pre-establishment national treatment - would appear to have violated the China FIPPA had the foreign purchaser been a Chinese company. ${ }^{86}$

In contrast, the FIPPA provides China the ability to screen Canadian investment under any of China's “Laws, Regulations and Rules relating to the regulation of foreign investment”. None of these unspecified laws, regulations, or rules are limited to China’s national government meaning that Chinese sub-national governments, including even local governments, retain the ability to block Canadian investments. ${ }^{87}$ As a result, even if China were to allow market access to third-state investors (and by extension to Canadian investors) in a future treaty, China would retain the ability to block market access by Canadian investors at any level of Chinese government.

\footnotetext{
${ }^{85}$ Infra note 96.

${ }^{86}$ Marina Strauss and Bertrand Marotte, “Quebec eyes buying Rona shares to block Lowe’s” The Globe and Mail (31 July 2012). Incidentally, under NAFTA, supra note 3, Article 1108(1)(a)(ii), sub-national decisions are exempted from the NAFTA national treatment obligation.

${ }^{87}$ For an indication of the potential significance of this carve-out, see David Fung's comment (offered by him as a reason for Canada to conclude the China FIPPA but without reference to the FIPPA's carve-out for investment screening and existing discriminatory measures in China): “There are lots of horror stories about Canadian investments in China.... In Canada, our cities don't go and destroy somebody else's investment. But, in China, a mayor has a lot more power than our mayors in Canada.” David Fung, Vice chair of the Canada China Business Council, quoted in Keith Norbury, “Canada-China FIPA: A good deal for Canadian investors, or not?” Canadian Sailings (14 April 2013), available online: http://www.canadiansailings.ca/?p=6437 (last accessed 26 January 2014).
} 
Second, the carve-out for China is not limited to a specific legal instrument akin to the Investment Canada Act. Rather, the FIPPA refers to "Laws, Regulations and Rules”. This gives China the ability to screen Canadian investment on a much wider basis than Canada, whose flexibility in investment screening is limited to the Investment Canada Act presumably as it stood at the time of the FIPPA's entry into force. This lack of reciprocity is important because, with the exception of review on national security grounds, ${ }^{88}$ the Investment Canada Act has significant limitations as a vehicle for investment screening. For example, the Investment Canada Act authorizes the federal government to block an investment only if the investment involves the takeover of a Canadian company; i.e. the federal government cannot block greenfield investment. ${ }^{89}$ Further, even if a Chinese investment involved the takeover of a Canadian firm, the Investment Canada Act permits review of the investment only if the value of the Canadian firm subject to the takeover exceeds a general threshold of $\$ 344$ million (in 2013) that is expected to rise to $\$ 1$ billion by $2018 .{ }^{90}$ To illustrate, a series of largescale land purchases by Chinese companies - an issue that has attracted attention elsewhere ${ }^{91}$ - could take place parcel-by-parcel below the Investment Canada Act threshold, with no ability under the FIPPA for the federal government to screen the investment without exposure to viable ISA claims.

\footnotetext{
${ }^{88}$ Investment Canada Act, supra note 9, s. 25.1.

${ }^{89}$ Ibid, s. 14(1).

${ }^{90}$ Industry Canada, "Investment Canada Act - Thresholds for Review” (last modified 13 January 2013), available online:

http://www.ic.gc.ca/eic/site/ica-lic.nsf/eng/h_lk00050.html (last accessed 26 January 2014). The thresholds are different for takeovers by stateowned enterprises; Industry Canada, “Investment Canada Act - Guidelines on Investment by state-owned enterprises: net benefit assessment”, available online: https://www.ic.gc.ca/eic/site/ica-lic.nsf/eng/lk00064.html\#p2 (last modified 7 December 2012).

${ }^{91}$ Lorenzo Cotula et al, Land grab or development opportunity? (London/ Rome: International Institute for Environment and Development/ Food and Agriculture Organization of the United Nations/ International Fund for Agricultural Development, 2009) at 36 and 55; Klaus Deininger and Derek Byerlee, Rising Global Interest in Farmland (Washington: World Bank, 2011) at 53. For a discussion of how Chinese state-owned enterprises (SOEs) may purchase land directly to avoid investment screening under the federal government's 2012 restrictions on SOE takeovers in the resource sector, see Nathan Vanderklippe, “For China, an oil sands investment that can’t be blocked” The Globe and Mail (11 March 2014).
} 
In addition, under the Investment Canada Act, there are ways in which foreign takeovers of Canadian firms may proceed without any review by the federal government. ${ }^{92}$ For example, where a foreign-owned company is expanding, rather than acquiring, an existing business in Canada, the Investment Canada Act does not apply. ${ }^{93}$ This aspect of the Investment Canada Act incidentally appeared to raise concern after the federal government approved the Chinese National Offshore Oil Company (CNOOC)'s takeover of Nexen in 2012. ${ }^{94}$ The concern was that the approval, in combination with the China FIPPA, would allow further takeovers of Canadian assets by CNOOC without any additional review under the Investment Canada Act. ${ }^{95}$

Thus, in various respects, the FIPPA's carve-out of investment screening is non-reciprocal in favour of China. The FIPPA limits Canada's ability to screen Chinese investments to the Investment Canada Act while preserving China's ability to screen Canadian investments at any level of government and without thresholds or other limitations contained in the Investment Canada Act. This nonreciprocity is unique to the China FIPPA compared to Canada's other treaties that provide for market access subject to ISA. ${ }^{96}$ It also highlights that the Investment Canada Act is not as watertight a means to regulate Chinese investment as some have claimed in

\footnotetext{
${ }^{92}$ Investment Canada Act, supra note 9, s. 38; Industry Canada, “Investment Canada Act - Related-Business Guidelines”, available online: https://www.ic.gc.ca/eic/site/ica-lic.nsf/eng/lk00064.html\#p2 (last modified 7 December 2012).

${ }^{93}$ Ibid.

${ }^{94}$ Shawn McCarthy and Steven Chase, “Ottawa approves Nexen, Progress foreign takeovers” The Globe and Mail (7 December 2012).

${ }^{95}$ Kelly Cryderman, “Ottawa's foreign ownership strategy hurts Alberta, Mulcair argues” The Globe and Mail (19 February 2013). The concern appears credible, at least, assuming that the China FIPPA, if ratified, would implicitly preclude future changes to the Investment Canada Act (as conditioned by existing instruments such as the Related-Business Guidelines, supra note 92) that expanded the scope of Annex D.34 of the FIPPA.

${ }^{96}$ See Canada's FIPPAs with Costa Rica (Annex I(VI)(1) and (2)); Croatia (Annex I(VI)(1) and (2)); Ecuador (Article II(4)(a) and (b)); Egypt (Article II(4)(a) and (b)); Latvia (Article II(4)(a) and (b)); Panama (Article II(4)(a) and (b)); Philippines (Article II(4) and (5)); Romania (Article II(4)(a) and (b)), Trinidad and Tobago (Article II(4)(a) and (b)), Ukraine (Article II(4)(a) and (b)), Uruguay (Annex I(VI)(1) and (2)), and Venezuela (Annex II(3)(a) and (b)). [Annex to this article (reproducing findings recorded in the attached Excel spreadsheet) and/ or the texts of Canada's relevant treaties, available online: http://www.international.gc.ca/trade-agreements-accords-commerciaux/agr-acc/fipaapie/index.aspx?lang=eng (last accessed 26 January 2014).]
} 
relation to the FIPPA. ${ }^{97}$ For a watertight carve-out, Canada should have secured language equivalent to that obtained by China in the China FIPPA or by Canada in other FIPPAs. ${ }^{98}$

3. Apparent non-reciprocity on post-establishment national treatment

The China FIPPA provides for post-establishment national treatment. However, the FIPPA also includes broad exceptions to this general obligation of non-discrimination between domestic investors and established foreign investors. ${ }^{99}$ Perhaps most importantly, the FIPPA exempts existing non-conforming measures in Canada and China from post-establishment national treatment (and from both pre- and post-establishment MFN treatment). ${ }^{100}$ Thus, Canada and China, after an investment has been made, are permitted to continue to discriminate in favour of domestic investors to the detriment of investors of the other state so long as the discrimination is based on an existing rather than a new statute, regulation, policy, practice, etc. ${ }^{101}$ Further, Canada and China are required to lock in i.e. not increase - the existing levels of discrimination. ${ }^{102}$

\footnotetext{
${ }^{97}$ e.g. Greg Kanargelidis, Aaron Libbey, and Tamara Nachmani, “Canada-China Investment Treaty: Ratification Process Begins”, Blakes Bulletin (1 October 2012) ("while some critics have attached the Canada-China FIPA, arguing it results in a forfeiture of Canadian sovereignty with respect to Chinese foreign investment in Canada, this exception [for the Investment Canada Act] ensures the Government of Canada retains the ability to exercise oversight in this area").

${ }_{98}^{98}$ e.g. Agreement Between the Government of Canada and the Government of the Eastern Republic of Uruguay for the Promotion and Protection of Investments, Canada and Uruguay, 29 October 1997, entered into force 2 June 1999, Annex I(VI)(1) ("Decisions of a Contracting Party as to whether or not to permit establishment of a new business enterprise, or acquisition of an existing business enterprise or a share of such enterprise, by investors or prospective investors of the other Contracting Party shall not be subject to dispute settlement [i.e. investor-state arbitration] under Article XII of this Agreement”); supra note 96.

${ }^{99}$ China FIPPA, supra note 2, Article 8(2) to (5). Less significantly, these exceptions also apply to the FIPPA's provisions on senior management requirements and on pre- and post-establishment MFN treatment.

${ }^{100}$ Ibid, Article 8(2)(a)(i).

${ }^{101}$ See the definition of "measure" in ibid, Article 1(6).

102 Ibid, Article 8(2)(c).
} 
With some important exceptions, ${ }^{103}$ most of Canada's treaties that provide for ISA, like the China FIPPA, exclude existing nonconforming measures from post-establishment national treatment. ${ }^{104}$ Yet for the China FIPPA this feature seems especially noteworthy due to the de facto non-reciprocity it presumably creates. Indeed, it appears at present that there would be vastly more discriminatory measures in China than in Canada and that the measures in China may be more opaque and difficult for a Canadian investor to pinpoint as "existing” at a particular point in time than vice versa. In 2013, based on a survey of its members, the U.S.China Business Council (USCBC) reported as follows on the business environment in China: ${ }^{105}$

Respondents most frequently claimed to have experienced protectionism in licensing and regulatory approvals, while also noting discriminatory enforcement and preferential policies favoring domestic Chinese companies in many forms.

Fundamentally, there continues to be a significant difference in how foreign companies are treated, both formally and informally, versus their domestic Chinese counterparts. As one respondent noted, 'As long as the term "foreign-invested company” exists [in Chinese policies and regulations], the competition will not be very fair and the discrimination will exist in some way.' In other words, there is an inherent element of bias in the system.

\footnotetext{
${ }^{103}$ In Canada's model FIPPA, three of Canada's trade agreements (including NAFTA), and two FIPPAs (with Jordan and Peru), the exception is limited to sub-national measures and extends to national measures only where the exempted relevant measure is listed specifically; e.g. Canada's Model FIPPA, supra note 26, Article 9(1)(a)(i). Also, Canada's trade agreements with Chile and Colombia go further by requiring a negative-list approach for exempted state/ provincial measures as well as national measures. See Annex II of this article.

${ }^{104}$ This is so for 22 of Canada's 25 FIPPAs. One other FIPPA (with Poland) appears not to provide for post-establishment national treatment at all. See Annex II of this article.

${ }^{105}$ US-China Business Council (USCBC), USCBC 2013 China Business Environment Survey Results: Tempered Optimism Continues amid Moderating Growth, Rising Costs, and Persistent Market Barriers (USCBC, 2013) at 5-6 and , available online: http://uschina.org/sites/default/files/USCBC\%E2\%80\%942013Member\%20Survey_0.pdf (last accessed 27 January 2014). The USCBC reported that its survey was conducted by the USCBC from US- and China-based executives among USCBC members and that the survey included a crosssection of US companies that do business in China. Further information on methodology, such as the survey size, was not provided in the USCBC report.
} 
That bias shows up in numerous ways, many of them overlapping. While each of the top 10 challenges could stand on its own, these issues magnify each other and often make resolution of the problems more complicated.

According to the USCBC report, among the top ten challenges faced by foreign companies in China, 61\% of survey respondents experienced challenges with administrative licensing, 49\% experienced tighter enforcement of rules for foreign companies, and 33\% reported that there were laws or regulations that specified differential treatment for domestic competitors. ${ }^{106}$ Importantly, under the terms of the China FIPPA, these categories of reported discriminatory or protectionist treatment would evidently be exempt from China's obligations of non-discrimination due to the FIPPA’s carve-out of existing discriminatory measures at all levels.

Assuming that the business environment reported by the USCBC affects Canadian as well as U.S. investors in China and that its discriminatory and protectionist character goes well beyond the comparable experience of foreign investors in Canada, the China FIPPA would lock in a playing field that is un-level in key respects. This conclusion was supported further by testimony of federal trade official Vernon MacKay with respect to the China FIPPA's provisions on non-discrimination: ${ }^{107}$

[Y]ou have to look at the two economies as they exist at the time that the treaty comes into force. And when you look at the Canadian economy, it's relatively open, in terms of protectionist measures and discriminatory measures. You look at the Chinese economy, and they are more protectionist and they do have rules in place that allow them to discriminate in favour of Chinese investment.... So... at the time that this comes into force, you will have a relatively open Canadian economy locked in place, in terms of its ability to discriminate, and a less open, more closed economy locked in place at the time it comes into force....

\footnotetext{
${ }^{106}$ Ibid, 5-6 and 11-12.

107 e.g. Cross-Examination on Affidavit of Vernon John MacKay, supra note 1 at 40-1.
} 
A proper study of this apparent de facto non-reciprocity arising from the China FIPPA would require a comprehensive analysis of China’s approach to internal economic regulation compared to Canada's other treaty partners. To the author's knowledge, no such study has been carried out in relation to the China FIPPA. Based on available evidence, it is prudent to conclude that the China FIPPA is likely highly unequal in its effects due to the carve-out of existing discriminatory measures in Canada and China.

Incidentally, China's preservation of the right to maintain existing discriminatory measures would provide Chinese governments with a powerful tool to bargain with or take punitive measures against any Canadian investor in a situation of conflict over the investor's regulatory treatment. For example, if a decision-maker in China wanted to "destroy" 108 a Canadian investor, this could be pursued without violating the FIPPA by imposing discriminatory requirements pursuant to any law or regulation that was existing when the FIPPA entered into force. Thus, the non-reciprocity of post-establishment national treatment in the China FIPPA - and the greater flexibility that this preserves for Chinese discriminatory measures - undermines claims that the FIPPA will provide strong protections for Canadian investors in China.

\section{Reach-back in the scope of MFN treatment}

The FIPPA contains provisions that appear to safeguard the regulatory interests of states in the face of the FIPPA's investor protections. In particular, language in the FIPPA would likely constrain some of the far-reaching interpretations - common in investment treaty arbitration - of concepts of fair and equitable treatment, full protection and security, and indirect expropriation. ${ }^{109}$ For Canada, this limiting language dates from 2001 when the NAFTA states issued a statement of interpretation to rein in NAFTA

\footnotetext{
108 See Fung, supra note 87.

109 Supra notes 43 and 45.
} 
tribunals and Canada subsequently incorporated the language in its subsequent treaties. ${ }^{110}$ In the China FIPPA, the language has been highlighted by FIPPA proponents as reason for reassurance about the FIPPA's impacts on governments and legislatures. ${ }^{111}$ Yet the applicability of the limiting language - assuming it has a meaningful effect on interpretations given to the relevant substantive standards ${ }^{112}$ - is open to serious doubt due to the FIPPA's temporal "reach-back” on MFN treatment. ${ }^{113}$

Based on their obligations of MFN treatment, Canada and China must give no less favourable treatment to foreign investors from the other state party as compared to the treatment given in like circumstances to foreign investors from any third state. As such, the point of comparison for MFN treatment is the host state's treatment of third-state investors while for national treatment it is the host state's treatment of domestic investors. In this respect, the FIPPA’s MFN provision is unremarkable.

More significantly, the China FIPPA extends expressly its MFN treatment obligation beyond any treatment given to third-state investors in future treaties to include any treatment given in previous treaties since $1994 .{ }^{114}$ This approach differs from all but two FIPPAs ${ }^{115}$ concluded by Canada in that it makes clear that MFN treatment extends to treatment afforded to third-state investors in past

\footnotetext{
${ }^{110}$ Canada's Model FIPPA, supra note 26, Article 38(1) to (4). See also Canada’s post-2001 FIPPAs with the Czech Republic, Jordan, Latvia, Peru, Romania, the Slovak Republic, and Tanzania and Canada’s trade agreements with Colombia, Panama, and Peru. See Annex I of this article. 111 e.g. Cross-Examination on Affidavit of Vernon John MacKay, supra note 1 at 43, 53, and 66.

${ }^{112}$ For a contrary position, adopted by the federal government, that the limiting language makes no difference to the meaning of the substantive standard of fair and equitable treatment, see Chemtura Corporation v Government of Canada (Respondent Counter-Memorial, 20 October 2008) at para 896. The tribunal in that case appeared not resolve this particular issue; Chemtura Corporation v Government of Canada (Award, 2 August 2010) at para 235.

${ }^{113}$ Howard Mann, “The Canada-China investment treaty sleight of hand” Embassy News (8 January 2013).

${ }^{114}$ China FIPPA, supra note 2, Article 8(1)(b) (MFN treatment does not apply to "treatment accorded under any bilateral or multilateral international agreement in force prior to 1 January 1994”). MFN treatment also does not extend to trade agreements (China FIPPA, supra note 2, Article 8(1)(a)(i)) but this does not affect the present analysis because the express application of MFN treatment to post-1993 FIPPAs is sufficient to undermine Canada's post-2001 limiting language assuming that the pre-2001 language provides more favourable treatment to foreign investors than the post-2001 language.

${ }^{115}$ These are Canada's FIPPAs with Jordan (in 2009) and Tanzania (in 2013). See Annex II of this article.
} 
FIPPAs. Other treaties concluded by Canada either preclude expressly ${ }^{116}$ or are silent on ${ }^{117}$ the application of MFN treatment to previous treaties. The China FIPPA's express reach-back also differs from Canada's model FIPPA which says that MFN treatment "shall not apply to treatment under all bilateral or multilateral international agreements in force or signed prior to the date of entry into force of this Agreement”. ${ }^{118}$ Thus, while Canada’s model FIPPA states expressly that MFN treatment does not allow foreign investors to mix-and-match provisions from previous treaties as a creative legal strategy, the China FIPPA makes clear that they can. ${ }^{119}$

For present purposes, the significance of this complex reach-back on MFN treatment is that it puts the China FIPPA's limiting language, highlighted above, at serious risk. Perhaps most significant is the risk to the FIPPA's limiting language on fair and equitable treatment and full protection and security given the extent to which investment treaty tribunals have interpreted these concepts expansively in favour of claimant investors. ${ }^{120}$ To elaborate, the FIPPA's limiting language appears to restrict such expansive interpretations by clarifying that the concepts in question "do not require treatment in addition to or beyond that which is required by the international law minimum standard of treatment of aliens as evidenced by State practice accepted as law". ${ }^{121}$ In other words, the FIPPA affirms that the concepts are limited to their customary meaning based on the usual evidentiary requirements of customary international law and thus guards against arbitrators' introducing novel and intrusive state obligations as part of the obligations to

\footnotetext{
${ }^{116}$ These are Canada's FIPPA with Peru and the Canada-Chile trade agreement. See Annex II of this article.

${ }^{117}$ This is the case for the remaining 26 of Canada's treaties that provide for ISA. See Annex II of this article.

${ }^{118}$ Canada's model FIPPA, supra note 26, Annex III(1).

${ }^{119}$ Stephan W. Schill, The Multilateralization of International Investment Law (Cambridge: CUP, 2009) at 140-2. For a discussion of rationales for limiting this mix-and-match approach as well as limiting the implied application of MFN treatment to past treaties, see Tony Cole, The Structure of Investment Arbitration (Milton Park: Routledge, 2013) at 97-112.

${ }^{120}$ Roland Kläger, "Fair and Equitable Treatment” in International Investment Law (Cambridge: CUP, 2011) at 116-9; M Sornarajah, "Evolution or Revolution in International Investment Arbitration? The Descent into Normlessness" in Chester Brown and Kate Miles, Evolution in Investment Treaty Law and Arbitration (Cambridge: CUP, 2011) at 650-2; Stephan W Schill, "Fair and Equitable Treatment, the Rule of Law, and Comparative Public Law” in Stephan W Schill, ed, International Investment Law and Comparative Public Law (Oxford: OUP, 2010) at 159-70; Alexandra Diehl, The Core Standard of International Investment Protection (Alphen aan den Rijn: Kluwer Law International, 2012 ) at ch 6.

${ }^{121}$ China FIPPA, supra note 2, Article 4(2).
} 
guarantee fair and equitable treatment or full protection and security. ${ }^{122}$ Similarly, on indirect expropriation, the FIPPA provides among other things: ${ }^{123}$

Except in rare circumstances, such as if a measure or series of measures is so severe in light of its purpose that it cannot be reasonably viewed as having been adopted and applied in good faith, a non-discriminatory measure or series of measures of a Contracting Party that is designed and applied to protection the legitimate public objectives for the well-being of citizens, such as health, safety and the environment, does not constitute indirect expropriation.

This language likewise responds to expansive approaches by arbitrators in, for example, the early NAFTA award in Metalclad $v$ Mexico, where the tribunal adopted a far-reaching approach to indirect expropriation. ${ }^{124}$ It is unclear how ISA tribunals under the China FIPPA would respond to the limiting language on these concepts given the prevalence of expansive approaches. ${ }^{125}$ Yet the limiting language is at least an important factor weighing against expansive interpretations that may frustrate legitimate regulatory interests of Canada or China. ${ }^{126}$

\footnotetext{
${ }^{122}$ The language also makes clear the requirement that claimants, in order to establish an evolution of the meaning of international custom, must supply evidence of state practice and opinio juris. This is a point on which few ISA tribunals have held claimants to the customary evidentiary requirements. Matthew C. Porterfield, “A Distinction Without a Difference? The Interpretation of Fair and Equitable Treatment Under Customary International Law by Investment Tribunals” Investment Treaty News (22 March 2013).

${ }^{123}$ China FIPPA, supra note 2, Annex B.10.

${ }^{124}$ Metalclad v Mexico (2000), 40 ILM 36 at para 103 (ICSID Additional Facility); see also United Mexican States v Metalclad Corporation, 2001 BCSC 664 at para 99. The Metalclad award is still widely-cited by ISA tribunals; e.g. Occidental v Ecuador (No 2) (2012), ICSID Case No $\mathrm{ARB} / 06 / 11$ at para 455 (ICSID).

${ }^{125}$ For example, ISA tribunals have incorporated new concepts as part of the customary international standard without requiring the claimant to provide evidence of state practice and opinio juris; e.g. Railroad Development Corporation v Guatemala (2012), ICSID Case No ARB/07/23 at paras 207-11 and 216-19 (ICSID). Porterfield, supra note 122.

${ }^{126}$ Judging from the NAFTA experience, the limiting language has gone some way to rein in arbitrators' approaches to relevant concepts even if variation remains and even if, outside NAFTA, ISA tribunals typically take a more expansive approach; supra notes 46 and 120 . Luke Eric
} 
Critically, the FIPPA’s reach-back on MFN treatment casts serious doubt about all of the limiting language discussed above. This is because both Canada and China have concluded treaties since 1994 that do not incorporate the limiting language ${ }^{127}$ and, as a result, have assumed a significant risk of being unable to rely on the limiting language due to their obligation to provide MFN treatment. In Canada's case, therefore, a Chinese investor would be able to argue that it is entitled to no less favourable treatment than that enjoyed by third-state investors under any of Canada's 14 post-1994 FIPPAs in which fair and equitable treatment, full protection and security, and indirect expropriation are not subject to the limiting language. ${ }^{128}$

For various reasons, it is at least likely that an ISA tribunal would decide that the China FIPPA's limiting language amounts to less favourable treatment relative to the treatment of third- state investors under Canada's other FIPPAs. First, MFN treatment has been interpreted broadly - in that it has been extended to treatment relating to dispute settlement provisions rather than simply substantive provisions in other treaties - by about half of the 20 ISA tribunals that faced and resolved this particular issue in publicly-available awards up to May-June 2010. ${ }^{129}$ Second, even if a tribunal under the China FIPPA adopted a more restrictive approach by limiting MFN treatment to substantive provisions only, the FIPPA's limiting language would still be in jeopardy because it affects treatment provided in the FIPPA's substantive provisions rather than dispute settlement.

Peterson, “Evaluating Canada’s 2004 Model Foreign Investment Protection Agreement in Light of Civil Society Concerns”, Report for the Canadian Council for International Co-operation (June 2006).

${ }^{127}$ e.g. Agreement Between the Government of Canada and the Government of the Republic of Croatia for the Promotion and Protection of Investments, Canada and Croatia, 3 February 1997, entered into force 30 January 2001; Agreement on encouragement and reciprocal protection of investments between the Government of the People's Republic of China and the Government of the Kingdom of the Netherlands, China and the Netherlands, 26 November 2001, entered into force 1 August 2004. These treaty texts are available online: http://www.international.gc.ca/tradeagreements-accords-commerciaux/agr-acc/fipa-apie/index.aspx?lang=eng (last accessed 26 January 2014); http://www.unctadxi.org/templates/DocSearch_779.aspx (last accessed 26 January 2014).

${ }^{128}$ See Canada’s FIPPAs with Armenia, Barbados, Costa Rica, Croatia, Ecuador, Egypt, Lebanon, Panama, the Philippines, Thailand, Trinidad and Tobago, Ukraine, Uruguay, and Venezuela. See Annex I of this article.

${ }^{129}$ Van Harten, supra note 25 at 228 and 238. 
To illustrate, in Paushok v Mongolia, an ISA tribunal adopted a relatively restrictive (i.e. respondent state-friendly) approach to MFN treatment by declining to extend the concept either to treatment in dispute settlement provisions or to treatment in any new substantive provision in other treaties. According to the tribunal: ${ }^{130}$

... Historically, tribunals have tended to construe MFN clauses broadly and they have regularly accepted to import substantive rights into an investment treaty from treaties that the host State has signed with other countries. This broad interpretation has also led tribunals to allow the import of more favourable procedural rights. There are however other cases which have adopted a more restrictive interpretation concerning the import of procedural rights but this issue need not be addressed in the present case, the question relating simply to the import of substantive rights.

The Treaty is quite clear as to the interpretation to be given to the MFN clause...: the extension of substantive rights it allows only has to do with Article 3(1) which deals with fair and equitable treatment. If there exists any other BIT between Mongolia and another State which provides for a more generous provision relating to fair and equitable treatment, an investor under the Treaty is entitled to invoke it. But, such investor cannot use that MFN clause to introduce into the Treaty completely new substantive rights, such as those granted under an umbrella clause.

Based on this approach, and on the contained terms of the relevant BIT, the concept of MFN treatment was extended to substantive rights only in circumstances where a more generous version of the same substantive right had been included in the treaty with a thirdstate. Yet, even on this restrictive approach, foreign investors under the China FIPPA would be relieved of its limiting language for the

\footnotetext{
${ }^{130}$ Paushok v Mongolia (Award, 28 April 2011) at paras 565 and 570 (UNCITRAL), available online: http://italaw.com/sites/default/files/casedocuments/ita0622.pdf (last accessed 30 January 2014).
} 
notions of fair and equitable treatment, full protection and security, and indirect expropriation on the basis that each concept forms part of a more generous version of the same substantive provision in other FIPPAs that lack the limiting language.

Further, if an ISA tribunal under the China FIPPA adopted an approach going beyond Paushok, as is common in other ISA awards, ${ }^{131}$ the tribunal could incorporate other provisions from other FIPPAs in order to expand investor protection further. For example, the China FIPPA's denial-of-benefits clause could be read down and rendered ineffective by reference to clauses in other FIPPAs that require Canada to give notice before invoking a denial-of-benefits clause in the face of an ISA claim. In this way, the reach-back on MFN treatment undermines a variety of limiting devices in the FIPPA, with implications for the apparent balance struck in the FIPPA between investor protection and regulatory flexibility.

Incidentally, this analysis of the effect of the China FIPPA's reach-back on MFN treatment has been rejected, or at least not adopted, by some commentators. ${ }^{132}$ Yet it appears that the federal government itself determined, as part of its negotiating strategy for the China FIPPA, to jeopardize its post-2001 limiting language in order to obtain for Canadian investors a similar ability to avoid the FIPPA's limiting language in ISA claims against China. When questioned under oath about the China FIPPA's reach-back on MFN treatment, federal trade official Vernon MacKay explained: ${ }^{133}$

China has over a hundred of what we call bilateral investment treaties very similar to FIPPAs. Most of them we would not want access to because they're not high-ambition - what we would call a high-ambition treaty. But there were a few in the early 2000s with some European countries that are pretty high standard. They’re not directly comparable, so it’s hard to say,

\footnotetext{
${ }^{131}$ Supra note 129.

132 e.g. Hupacasath First Nation v Canada (Foreign Affairs), 2013 FC 900 at para 103.

${ }^{133}$ Cross-Examination on Affidavit of Vernon John MacKay, supra note 1 at 51-3.
} 
you know, just how much more advantageous they might be to an investor, but they were - they were ones that we were considering.....

The fair and equitable standards of some of these treaties are very broadly worded, certainly worded in ways that we would not word ours, which could lend themselves to an expansive interpretation which our Canadian investors may take advantage of in a Chinese market situation....

[S]ome of these provisions were potentially more of a broader scope and could provide high - you know, more protection for a Canadian investor. So since - and just to clarify, the Canadian model, as we have included in here, does not include that reachback to 1994, but it is - we have the policy flexibility, if I could say that, to modify that.... We use that 1994 reach-back as an incentive to get the other party to reach back as well.

This testimony indicates that Canadian negotiators intended the reach-back on MFN treatment to expand the benefits of the China FIPPA for foreign investors at the expense of the regulatory interests of both Canada and China and, by extension, at the expense of other actors who may benefit from state conduct otherwise safeguarded by the limiting language. In turn, it is dubious based on the existing record of investment treaty arbitration and Mr. McKay’s testimony for anyone to rely on the FIPPA's limiting language as a safeguard for regulatory decision-making under the FIPPA. ${ }^{134}$

\footnotetext{
${ }^{134}$ e.g. Department of Foreign Affairs and International Trade (DFAIT), Final Environmental Assessment of the Canada-China Foreign Investment Protection Agreement (FIPA) (Ottawa: Government of Canada, undated), available online: http://www.international.gc.ca/tradeagreements-accords-commerciaux/agr-acc/china-chine/finalEA-china-chine-EEfinale.aspx?lang=eng (last accessed 27 January 2014) ("No new issues arose during the latter stages of the Canada-China FIPA negotiations with respect to potential environmental impacts in Canada.... [A]s is found in [Canada's FIPA] model, Annex B.10 of the Canada-China FIPA provides that regulations designed and applied to advance legitimate public welfare objectives, such as those respecting health, safety and the environment, do not constitute an indirect expropriation.”).
} 
5. Incorporation into the FIPPA of the TRIMs performance requirements clause

Like many treaties that reflect the North American approach, the China FIPPA has a prohibition on performance requirements essentially, measures that require foreign investors to export a certain share of their protection, to use domestic inputs, to employ domestic workers, and so on - that many states sometimes impose on foreign investors as a condition of operation in the state's territory and as part of a larger industrialization and development strategy. ${ }^{135}$ The China FIPPA's prohibition is not as far-reaching as the prohibition in other treaties concluded by Canada, including NAFTA. ${ }^{136}$ In particular, the China FIPPA’s prohibition is limited to the states parties' existing obligations under the WTO Trade-Related Investment Measures (TRIMs) Agreement which essentially require states not to discriminate between foreign and domestic investors in the case of a trade-related performance requirement. ${ }^{137}$

Importantly, by transplanting the TRIMS obligations into an investment treaty, the China FIPPA subjects the relevant obligations to ISA instead of WTO state-state adjudication. ${ }^{138}$ In ISA, arbitrators typically award retrospective compensation directly to a private party; at the WTO, tribunals authorize only prospective trade remedies to compensate the successful WTO state. ${ }^{139}$ Thus, in ISA, arbitrators award compensation that is calculated from the time of the state's original conduct that was found to have violated the treaty. Unlike at the WTO, the state typically has no opportunity to correct the declared illegality before having to pay potentially vast amounts of compensation to the claimant investor. As a result, ISA introduces the prospect of uncertain but irreversible and potentially very onerous liability whenever a legislature, government, or court pursues a course of action that may cause loss to a foreign investor.

\footnotetext{
${ }^{135}$ China FIPPA, supra note 2, Article 9.

${ }^{136}$ Compare NAFTA, supra note 3, Article 1106.

${ }^{137}$ In particular, the China FIPPA incorporates Article 2 and the Annex of the Agreement on Trade-Related Investment Measures, 15 April 1994 , 1868 UNTS 186 [TRIMS Agreement].

${ }^{138}$ Martin Molinuevo, Protecting Investment in Services: Investor-State Arbitration Versus WTO Dispute Settlement (Alphen aan den Rijn: Wolters Kluwer, 2012) at 72-4 and 233-4.

${ }^{139}$ Also, in contrast to WTO arbitration, the legal claims in ISA are formulated by private parties who are not subject to the treaty obligations and who do not have a corresponding interest to moderate their claims.
} 
This raises wider issues about the use of monetary remedies, without any limit on the amounts that can be awarded, ${ }^{140}$ as a remedy for unlawful sovereign conduct. ${ }^{141}$ More specifically, it highlights how TRIMS obligations on performance requirements take a different form when transplanted into a FIPPA and subjected to ISA. ${ }^{142}$

Because the TRIMs obligations are rarely incorporated into FIPPAs or other BITs, it is unclear how they will be applied in an investment as opposed to the trade context, although it is clearly possible that the obligations will be given a broader meaning. ${ }^{143}$ In any event, one may surmise the potential meaning of the China FIPPA's prohibition on performance requirements by considering how the relevant TRIMs obligations have been interpreted at the WTO. In the recent the WTO panel report on Ontario’s Green Energy Act and Feed-in Tariff (FIT) program, the WTO panel concluded: ${ }^{144}$

As to whether the measures are "trade-related", we note that the FIT Programme imposes a "Minimum Required Domestic Content Level” on electricity generators utilising solar PV and windpower technologies that, for the reasons we explain elsewhere in this section, compels them to purchase and use certain types of renewable energy generation equipment sourced in Ontario in the design and construction of their facilities. To this extent, we see the "Minimum Required Domestic Content

\footnotetext{
${ }^{140}$ Compare the monetary limits on penalties in person-to-government dispute resolution under Canada's Agreement on Internal Trade Consolidated Version, 2012, Annex 1707.1(2) (providing for a maximum penalty of \$5 million per case for the largest provinces), available online: http://www.ait-aci.ca/en/ait/ait_en.pdf (last accessed 27 January 2014).

${ }^{141}$ van Aaken, supra note 22.

${ }^{142}$ Two other FIPPAs refer to TRIMs obligations as prohibited performance requirements but both of these FIPPAs include the aboriginal exception: see Canada's FIPPAs with Thailand and Costa Rica. See Annex I of this article.

${ }^{143}$ Gus Van Harten, Investment Treaty Arbitration and Public Law (Oxford: OUP, 2007) at 73-80.

${ }^{144}$ Canada - Certain Measures Affecting the Renewable Energy Generation Sector/ Canada - Measures Relating to the Feed-In Tariff Program (2012), WTO Docs WT/DS412/R and WT/DS426/R at para 7.111 (Panel Reports) [emphasis added]; Canada - Certain Measures Affecting the Renewable Energy Generation Sector/ Canada - Measures Relating to the Feed-In Tariff Program (2013), WTO Docs WT/DS412/AB/R and WT/DS426/AB/R at para 5.6 (Reports of the Appellate Body) ("Domestic content requirements are one type of TRIM regulated under the TRIMS Agreement.”).
} 
Level” that is at issue in these disputes to be not unlike the domestic content requirements challenged in Indonesia - Autos, where the panel opined that "by definition, [domestic content requirements] always favour the use of domestic products over imported products, and therefore affect trade.

On this basis, it appears clear that a regulatory requirement for a foreign investor to use domestic suppliers or hire domestic workers as forms of "domestic content” in the investor's activities - would not be consistent with the TRIMS obligations and in turn with the China FIPPA. This is significant due to other aspects of the China FIPPA’s prohibition on performance requirements, discussed below.

6. Expanded application of the performance requirements clause

The China FIPPA's incorporation of TRIMs obligations on performance requirements is especially important because the China FIPPA does not incorporate all of the reservations and exceptions that usually apply to obligations on performance requirements in other treaties of Canada. ${ }^{145}$ In particular, in many or all of Canada's other treaties that provide for ISA, obligations on performance requirements do not extend to various measures such as existing provincial and municipal measures ${ }^{146}$ and measures that protect the rights and preferences of aboriginal peoples. ${ }^{147}$ On the latter measures, for example, NAFTA provides with respect to its prohibition

\footnotetext{
${ }^{145}$ For instance, of the 24 relevant treaties that contain an obligation on performance requirements, all have an exception for aboriginal rights and preferences. Likewise, Canada's model FIPPA, supra note 26, allows for similar reservations and exceptions. See Annex I of this article.

${ }^{146}$ e.g. NAFTA, supra note 3, Article 1108(1)(a)(ii) and (iii) (the relevant obligations “do not apply to... any existing non-conforming measure that is maintained by... a state or province... or... a local government”. Note: this NAFTA clause provides that the reserved state and provincial measures must be listed within two years in a separate Schedule; the Schedule was never completed, leaving by implication a reservation for all existing non-conforming measures of states and provinces). The sole exceptions appear to be Canada's trade agreements with Chile and Colombia.

${ }^{147}$ Supra note 145.
} 
on performance requirements that "Canada reserves the right to adopt or maintain any measure denying investors of another Party and their investments, or service providers of another Party, any rights or preferences provided to aboriginal peoples.”148

It is noteworthy by contrast that the China FIPPA does not extend the same reservations to its obligations on performance requirements. ${ }^{149}$ As a result, the FIPPA would newly prohibit and subjects to ISA a range of federal, provincial, and municipal measures in Canada as they affect Chinese investors. Further, U.S. and other foreign investors in Canada would be newly entitled to the same insulation from performance requirements - on a non-reciprocal basis in comparison to Canadian investors in the U.S. or the other third-state - due to the MFN treatment obligations in NAFTA and other treaties of Canada that provide for ISA.

In this respect, the China FIPPA marks a significant departure from Canada's past practice on performance requirements and ISA. This may have significant consequences for Canadian businesses and employees whose contracts or jobs are linked to a regulatory requirement in Canada that foreign investors use domestic suppliers or domestic workers. It appears especially relevant in the resource sector in light of government efforts to enhance value-added benefits of resource extraction in Canada for the Canadian economy. The potential conflict was highlighted in 2012 when Canada lost an ISA claim under NAFTA in Mobil Oil v Canada. ${ }^{150}$ In that case, a majority of the tribunal decided that Canada had violated NAFTA's prohibition on performance requirements after changes were made to research-and-development (R \& D) expenditure rules for domestic and companies operating in Newfoundland and Labrador’s

\footnotetext{
${ }^{148}$ NAFTA, supra note 3, Annex II (Schedule of Canada). Similarly, other state measures in some areas, such as the protection of rights of disadvantaged minorities, are also exempted in NAFTA and some other FIPPAs. See Annex I.

${ }^{149}$ China FIPPA, supra note 2, Article 8(2)(a)(i) and Annex B.8, which incorporate into the China FIPPA a series of reservations contained in the Free Trade Agreement between Canada and the Republic of Peru, Canada and Peru, 29 May 2008, entered into force 1 August 2009, Annex II; and in the Free Trade Agreement between China and the Republic of Peru, China and Peru, 28 April 2009, entered into force 1 March 2010, Chapter 10.

${ }^{150}$ Mobil Investments Canada Inc and Murphy Oil Corp v Canada (2012), ICSID Case No ARB(AF)/07/4 (ICSID Additional Facility), available online: http://www.italaw.com/sites/default/files/case-documents/italaw1145.pdf (last accessed 27 January 2014).
} 
offshore oil sector. ${ }^{151}$ Surprisingly, the tribunal also concluded that the changes were not safeguarded by Canada's reservation under NAFTA for the law that authorized the R \& D rules. ${ }^{152}$ For present purposes, the decision indicates that prohibitions on performance requirements in the China FIPPA may clash with domestic social or economic policies.

The China FIPPA's divergence from Canada's past practice on performance requirements appears particularly significant in relation to aboriginal peoples. Besides the China FIPPA, all of Canada's treaties that prohibit performance requirements include a reservation from the prohibition for measures that protect aboriginal rights and preferences. By implication, the China FIPPA would newly prohibit any requirements in Canada that foreign investors use aboriginal (i.e. domestic) content as a condition of their operation. This change would appear to preclude aspects of so-called impact and benefit agreements in Canada that typically require, among other things, the use of aboriginal content in resource projects and that are in some cases required by law for foreign investors, especially in the resource sector. ${ }^{153}$ Thus, although such agreements are widespread as a means to accommodate aboriginal rights and interests and avoid potential disputes, ${ }^{154}$ under the China FIPPA it appears that they would be newly prohibited and subject to ISA.

In light of this change, one might have expected the federal government to consult with provincial and municipal governments and First Nations to evaluate how existing measures may be affected uniquely by the China FIPPA. One might also expect that

\footnotetext{
${ }^{151}$ Ibid, para 246.

${ }^{152}$ Ibid, paras 410-16. For a critical comment on the award, see Nigel Bankes, "From Regulatory Chill to Regulatory Concussion: NAFTA’s Prohibition on Domestic Performance Requirements and an Absurdly Narrow Interpretation of Country Specific Reservations”, Case comment (6 May 2013), available online: http://ablawg.ca/wp-content/uploads/2013/05/Blog_NB_Mobil_Investments_May20131.pdf.

${ }^{153}$ Sandra Gogal, Richard Riegert, and JoAnn Jamieson, “Aboriginal Impact and Benefit Agreements: Practical Considerations” (2005) 43 Alberta L Rev 129; Courtney Fidler and Michael Hitch, "Impact and Benefit Agreements: A Contentious Issue for Environmental and Aboriginal Justice” (2007) 35:2 Environments Journal 49 at 61.

${ }^{154}$ A joint government task force reported in 2010 that aboriginal organizations and mining companies concluded 91 agreements during $1998-$ 2008 that were "designed to secure both benefits for Aboriginal communities and certainty for exploration and mining companies" and that may include, for example, "preferential hiring practices for Aboriginal workers”. Federal, Provincial and Territorial Social Licence Task Group, Mining Sector Performance Report - 1998-2008 (Ottawa: Government of Canada, 2010) at 27.
} 
governments would examine how the change could impact domestic companies or workers that are connected to foreign companies. Yet in 2012 it was disclosed in litigation that the federal government did not consult with other policy actors such as municipalities and First Nations after deciding that no consultation over the China FIPPA was required. According to testimony by federal trade official Vernon MacKay: ${ }^{155}$

[T] he design of the treaty did not lead us to consult with aboriginal peoples, it did not lead us to consult with other policy communities such as municipalities, because our China FIPA stuck to the model, the model FIPA, which is an agreement that we have had in place since 1994, since the NAFTA. This is a perfect example of - it's a member of a family of investment agreements that Canada has had in place since 1994, in terms of FIPAs or also investment chapters of free trade agreements. So there is no departure from our past practice in that regard, and it did not lead us to a decision on whether we should be consulting more broadly than we already were.

Further: ${ }^{156}$

Question: [T]o your knowledge, was any consideration given to how the exercise of First Nations governance might be affected by the ratification of the Canada-China FIPA?

Answer: There was no specific analysis done on that question, nor was there specific analysis done on how, for example, the FIPA might affect municipalities. And the reason for that is that it did not depart from our FIPA model, and we are very comfortable with the impacts of that FIPA model on the various policy communities that are covered by this treaty.

\footnotetext{
${ }^{155}$ Cross-Examination on Affidavit of Vernon John MacKay, supra note 1, 9. ${ }^{156}$ Ibid, 11.
} 
This lack of consultation appears problematic due to the FIPPA's evident uniqueness with respect to performance requirements and other issues and the potential impact on Canadian companies, workers, First Nations, and municipalities.

7. Allowance for confidentiality in investor-state arbitration

When ISA first attracted attention in the late 1990s, it became apparent that ISA claims and proceedings could be kept secret at the discretion of the ISA tribunal. In response, the NAFTA governments issued an interpretive statement in 2001 which clarified that nothing in NAFTA precluded the NAFTA states from publishing ISA awards and other documents and that ISA hearings under NAFTA could be open to the public. ${ }^{157}$ This was an important and positive step in the wider context of ISA.

Beginning in 2001, Canada incorporated requirements for ISA transparency in all of its treaties that provide for ISA. ${ }^{158}$ Reflecting this, Canada's model FIPPA of 2004 states: ${ }^{159}$

1. Hearings held [in ISA] shall be open to the public. To the extent necessary to ensure the protection of confidential information, including business confidential information, the Tribunal may hold portions of hearings in camera....

3. All documents submitted to, or issued by, the Tribunal under this Section shall be publicly available, unless the disputing parties agree otherwise, subject to the deletion of confidential information.

\footnotetext{
${ }^{157}$ Supra note 42. Meg Kinnear and Robin Hansen, “The Influence of NAFTA Chapter 11 in the BIT Landscape” (2005) 12 UC Davis J Int’l L \& Policy 101 at 111.

${ }^{158}$ This includes Canada's model FIPPA, supra note 26; all Canada's post-2001 FIPPAs, with the Czech Republic FIPPA (which entered into force in 2012 and adopts the presumption that all documents are public but like the China FIPPA provides that hearings are public if the respondent state so decides), Jordan, Latvia, Peru, Romania, the Slovak Republic, and Tanzania; and all Canada's post-2001 trade agreements, with Colombia, Panama, and Peru. See Annex I of this article.

${ }^{159}$ Canada's model FIPPA, supra note 26, Article 38.
} 
4. Notwithstanding paragraph 3, any Tribunal award under this Section shall be publicly available, subject to the deletion of confidential information.

These provisions clarify that ISA hearings and awards are public, subject to specific exemptions for confidential information. Further, as a general principle, all documents submitted or issued in ISA are public unless the investor and respondent state both agree to make them confidential. This degree of transparency did not reach the openness of a judicial proceeding in which all documents before the court are public, subject to the court's discretion, but it did offer a relatively high level of public access in ISA and was clearly warranted due to the significance of ISA for public policy and public finance. ${ }^{160}$

The China FIPPA diverges considerably from this approach on ISA transparency. According to the FIPPA: ${ }^{161}$

1. Any Tribunal award... shall be publicly available, subject to the redaction of confidential information. Where a disputing Contracting Party determines that it is in the public interest to do so and notified the Tribunal of that determination, all other documents submitted to, or issued by, the Tribunal shall also be publicly available, subject to the redaction of confidential information.

2. Where, after consulting with a disputing investor, a disputing Contracting Party determines that it is in the public interest to do so and notifies the Tribunal of that determination, hearings held under this Party shall be open to the public. To the extent

\footnotetext{
160 Jeswald W. Salacuse, The Law of Investment Treaties (Oxford: OUP, 2010) at 354-7; Andreas Kulick, Global Public Interest in International Investment Law (Cambridge: CUP, 2012) at 1-2 and 94-7; Valentina Vadi, Public Health in International Investment Arbitration (London: Routledge, 2013) at 20-1 and 57-8; Van Harten, supra note 143 at 58-70

${ }^{161}$ China FIPPA, supra note 2, Article 28(1) and (2).
} 
necessary to ensure the protection of confidential information, including business confidential information, the Tribunal may hold portions of hearings in camera.

These provisions diverge from Canada's established approach in two main ways. First, they create a general presumption that all ISA documents other than awards will not be public unless the respondent state decides to release them. Second, they establish a general presumption that ISA hearings will not be public unless the respondent state decides otherwise. In both respects, the FIPPA shifts the default from openness to confidentiality. The China FIPPA is the only treaty in which Canada has diluted ISA transparency in this way since 2001 when the original concerns about ISA confidentiality came to light. ${ }^{162}$

As a result, under the China FIPPA, information of relevance to the public - such as a government's submissions or reasons for an investor's claim - can be kept from public scrutiny. Faced with an embarrassing claim under the FIPPA, a government would it seems have an incentive but also a right under the FIPPA to keep information about the claim, including the fact of its existence, confidential. In these circumstances, how would a member of the public or media seek further information about a claim if the claim itself is not public? On this basis, the FIPPA appears to support a presumption that claims against Canada or China may be resolved behind the scenes by, for example, the payment of public funds, changes to government decisions, or pressure on the foreign investor. ${ }^{163}$ Where a claim or settlement is controversial - such as in the case of Canada's NAFTA settlement in Ethyl v Canada, where the federal government withdrew a legislative ban on a gasoline additive amidst a heated public debate ${ }^{164}$ - the public may be

\footnotetext{
${ }^{162}$ Supra note 158.

${ }^{163}$ This extension of the period of presumed confidentiality, beyond the time at which an ISA claim is filed, exacerbates the existing concern that compensation may be paid or decisions altered due to ISA without public knowledge.

${ }^{164}$ Ethyl Corporation v Government of Canada (1998), 38 ILM 78. The settlement has been discussed as an apparent case of regulatory chill; e.g. K Traynor, "How Canada Became a Shill for Ethyl Corporation" (1998) 23:3 Intervenor (Canadian Environmental Law Association). On this, it is suggested here that the NAFTA claim by Ethyl Corporation - the manufacturer of the gasoline additive in question - was a significant factor in the federal government's decision to withdraw its prohibition. Also, the fact that the case attracted controversy highlights the importance of public
} 
unable to know how ISA has affected government decisions. More broadly, the lack of openness also undermines the independence and fairness of ISA. ${ }^{165}$

Incidentally, since 2001, Canada has been a champion of ISA transparency in international forums. As recently as 2010, in submissions to an UNCITRAL working group on ISA transparency, Canada commented: ${ }^{166}$

Canada’s Foreign Investment Promotion and Protection Agreements (FIPAs) and Free Trade Agreements (FTAs) contain provisions protecting and promoting investment. Over time, these treaties have included increasingly explicit provisions concerning the transparency of treaty-based investor-State arbitration....

With respect to dispute settlement, the [FIPA] model was revised to promote transparency. Article 38 of the updated model requires that all documents submitted to or issued by the Tribunal, including hearing transcripts, be made public subject to redaction for confidential, privileged or third party business information. Further, all hearings are to be open to the public, subject only to closure when necessary to protect confidential business, privileged or third party information.

The federal government clearly has compromised this position in the China FIPPA.

access to ISA documents and indicates the potential interest of government to withhold embarrassing information about ISA claims and settlements.

${ }^{165}$ Theodor Meron, “Judicial Independence and Impartiality in International Criminal Tribunals” (2005) 99 AJIL 359 at 360-1; Van Harten, supra note 19.

${ }^{166}$ UNCITRAL Working Group II (Arbitration and Conciliation), 53d Sess, UN Doc No A/CN.9/WG.II/WP.159/Add.1 (2010) [emphasis added]. 


\section{Duration}

The China FIPPA has a relatively long minimum lifespan. Under NAFTA, Canada can withdraw from the treaty including its investment chapter on 6-months' notice. ${ }^{167}$ Canada’s model FIPPA allows for termination after one-year's notice with a so-called survival clause that extends the treaty's obligations for another 15 years in the case of investments existing at the time of termination; in total, then, the model FIPPA has an effective minimum lifespan of 16 years.

The China FIPPA in contrast provides for a minimum term of 15 years after which either state party can withdraw on one-year's notice, subject to a survival clause that extends the treaty for another 15 years for existing investments. ${ }^{168}$ Assuming substantial Chinese asset ownership in Canada at the time of termination, the China FIPPA if ratified would endure for at least 31 years unless both China and Canada agreed to the contrary. This puts the FIPPA's lifespan at the far upper end of Canada's treaties. As indicated in Table 1, only three FIPPAs currently in force - with Egypt, Hungary, and Poland - have a comparable minimum duration among the 30 relevant treaties of Canada. Only one FIPPA like the China FIPPA has a formal minimum term of 15 years. Only four FIPPAs have any formal minimum term at all.

\footnotetext{
${ }^{167}$ NAFTA, supra note 3, Article 2205.

${ }^{168}$ China FIPPA, supra note 2, Article 35(1) to (3).
} 
DRAFT/ Accepted for publication: Canadian Yearbook of International Law/ Annuaire Canadien de droit international (2014)

$\underline{\text { Table 1: Minimum duration of Canada’s treaties providing for investor-state arbitration }}{ }^{169}$

\begin{tabular}{|c|c|c|c|c|}
\hline Treaty & Minimum term & $\begin{array}{l}\text { Notice to } \\
\text { terminate }\end{array}$ & Survival clause & $\begin{array}{l}\text { Effective } \\
\text { minimum } \\
\text { duration }\end{array}$ \\
\hline China FIPPA & 15 years & 1 year & 15 years & 31 years \\
\hline Egypt FIPPA & 15 & 1 & 15 & 31 \\
\hline Hungary FIPPA & 10 & 1 & 20 & 31 \\
\hline Poland FIPPA & 10 & 1 & 20 & 31 \\
\hline Tanzania FIPPA & 10 & 1 & 15 & 26 \\
\hline Lebanon FIPPA & 0 & 1 & 20 & 21 \\
\hline Russia FIPPA & 0 & 1 & 20 & 21 \\
\hline Argentina FIPPA & 0 & 1 & 15 & 16 \\
\hline Armenia FIPPA & 0 & 1 & 15 & 16 \\
\hline Barbados FIPPA & 0 & 1 & 15 & 16 \\
\hline Costa Rica FIPPA & 0 & 1 & 15 & 16 \\
\hline Croatia FIPPA & 0 & 1 & 15 & 16 \\
\hline Czech Republic FIPPA & 0 & 1 & 15 & 16 \\
\hline Ecuador FIPPA & 0 & 1 & 15 & 16 \\
\hline Jordan FIPPA & 0 & 1 & 15 & 16 \\
\hline Latvia FIPPA & 0 & 1 & 15 & 16 \\
\hline Panama FIPPA & 0 & 1 & 15 & 16 \\
\hline Peru FIPPA & 0 & 1 & 15 & 16 \\
\hline Philippines FIPPA & 0 & 1 & 15 & 16 \\
\hline Romania FIPPA & 0 & 1 & 15 & 16 \\
\hline Slovak Republic FIPPA & 0 & 1 & 15 & 16 \\
\hline Thailand FIPPA & 0 & 1 & 15 & 16 \\
\hline Trinidad and Tobago FIPPA & 0 & 1 & 15 & 16 \\
\hline Uruguay FIPPA & 0 & 1 & 15 & 16 \\
\hline Venezuela FIPPA & 0 & 1 & 15 & 16 \\
\hline Ukraine FIPPA & 0 & 1 & 10 & 11 \\
\hline NAFTA & 0 & 0.5 & 0 & 0.5 \\
\hline
\end{tabular}

\footnotetext{
${ }^{169}$ Data compiled by author. All treaty texts are available online: http://www.international.gc.ca/trade-agreements-accords-commerciaux/agr-
} acc/fipa-apie/force-vigeur.aspx?lang=eng (last accessed 26 January 2014). 
DRAFT/ Accepted for publication: Canadian Yearbook of International Law/ Annuaire Canadien de droit international (2014)

\begin{tabular}{|l|l|l|l|l|}
\hline Canada-Panama FTA & 0 & 0.5 & 0 & 0.5 \\
\hline Canada-Peru FTA & 0 & 0.5 & 0 & 0.5 \\
\hline Canada-Colombia FTA & 0 & 0.5 & 0 & 0.5 \\
\hline Canada-Chile FTA & 0 & 0.5 & 0 & 0.5 \\
\hline & & & & \\
\hline Averages per treaty: & $\begin{array}{l}\text { Mean: } 1.9 \\
\text { Median: } 7.5\end{array}$ & $\begin{array}{l}\text { Mean: } 0.9 \\
\text { Median: } 0.75\end{array}$ & $\begin{array}{l}\text { Mean: } 13 \\
\text { Median: } 10\end{array}$ & $\begin{array}{l}\text { Mean: } 15.9 \\
\text { Median: } 15.25\end{array}$ \\
\hline
\end{tabular}

Further, the China FIPPA is for Canada obviously much more significant than Canada's FIPPAs with Egypt, Hungary, and Poland due to the size of the investment relationship to which the China FIPPA would apply. Investors from Egypt, Hungary, and Poland, and indeed from all countries with which Canada has a FIPPA, do not own assets in Canada that are comparable in value to the assets of Chinese investors. ${ }^{170}$ Among Canada's treaties that provide for ISA, only NAFTA compares and, unlike the China FIPPA, NAFTA can be terminated on 6-months' notice with no survival clause. ${ }^{171}$ The China FIPPA's 31-year minimum lifespan is thus an important variation from Canada's usual practice, thus escalating the significance of the FIPPA's other features.

\section{Broader context of the Canada-China investment relationship}

The evaluation in this article has focused thus far on textual aspects of the China FIPPA that are novel or non-reciprocal. An evaluation of the FIPPA in its wider context is beyond the scope of the paper. However, tentative comments are offered in this section using data on Canada-China FDI stocks as a commonplace measure of the relative significance of a BIT and, incidentally, as a further indicator of the FIPPA's de facto non-reciprocity in favour of China.

\footnotetext{
${ }^{170}$ Infra note 174.

${ }^{171}$ That said, for Canada, the adjustment cost of terminating NAFTA may presumably be much greater than the cost of terminating the China FIPPA or any other of Canada's FIPPAs or trade agreements.
} 
To begin, the China FIPPA differs from NAFTA and other trade agreements that include investment obligations within a wider trade treaty. The FIPPA, as a BIT, deals exclusively with investment and, especially, with the protection of foreign investors from various forms of state treatment. It is therefore more feasible to evaluate the FIPPA in its economic context of foreign ownership of assets, of costs and benefits arising from the additional legal protections for such assets, and of corresponding fiscal risks and legal constraints for states.

This is important because, other than NAFTA (where Canada may be said to have exchanged commitments on investment for greater trade-based market access to the U.S.), no trade or investment treaty approaches the economic significance of the China FIPPA for Canada. That is, since NAFTA, the federal government has not agreed to any treaty providing for ISA in which nationals of the other state party own substantial assets in Canada. ${ }^{172}$ Instead, the government has followed the conventional approach of Western states by accepting treaty-based ISA only where the Western state occupies the capital-exporting position in the investing relationship with the other state party and thus where the Western state does not assume equivalent risks and constraints arising from ISA. ${ }^{173}$ To illustrate, Table 2 outlines the amounts of inward and outward FDI - as a measure of foreign ownership - covered by Canada's relevant treaties.

\footnotetext{
${ }^{172}$ By “substantial” assets, I mean $\$ 1$ billion or more in inward FDI stocks.

173 Justin Carter, "The Protracted Bargain: Negotiating the Canada-China Foreign Investment Promotion and Protection Agreement” (2009) 47 Can YB Int’l L 197 at 205-6; Salacuse, supra note 160 at 91-7.
} 
$\underline{\text { Table 2: Inward and outward foreign direct investment in Canada }}{ }^{174}$

\begin{tabular}{|c|c|c|c|c|c|}
\hline \multirow[t]{2}{*}{ Country } & \multicolumn{2}{|c|}{$\begin{array}{l}\text { Inward FDI stocks (of foreign nationals in Canada, in } \\
\text { millions of dollars) }\end{array}$} & \multicolumn{2}{|c|}{$\begin{array}{l}\text { Outward FDI stocks (of Canadian nationals in } \\
\text { country, in millions of dollars) }\end{array}$} & \multirow{2}{*}{$\begin{array}{l}\text { Ratio of } \\
\text { outward to } \\
\text { inward FDI } \\
\text { stocks }\end{array}$} \\
\hline & $\begin{array}{l}\text { Annual average } \\
\text { during 2008-2012 }\end{array}$ & $\begin{array}{l}\text { Highest annual amount } \\
\text { during 2008-2012 (in } 2012 \\
\text { unless indicated otherwise) }\end{array}$ & $\begin{array}{l}\text { Annual average } \\
\text { during 2008-2012 }\end{array}$ & $\begin{array}{l}\text { Highest annual amount } \\
\text { during 2008-2012 (in } \\
2012 \text { unless indicated } \\
\text { otherwise) }\end{array}$ & \\
\hline USA & 309,356 & 326,527 & 272,224 & 289,426 & $1: 1.14$ \\
\hline China & 10,709 & 12,037 & 3,663 & 4,239 & $1: 2.9$ \\
\hline Barbados & 697 & 842 & 53,689 & 59,305 & $77: 1$ \\
\hline Russia & $653(\mathrm{a})$ & $1249(\mathrm{~h})$ & 2267 & 4816 & $3.5: 1$ \\
\hline Panama & 386 (f) & 386 (f) & 234 (b) & 415 (g) & $1: 1.6$ \\
\hline Mexico & 192 (c) & $121 \mathrm{i}$ & 5,021 & 5,569 & $26: 1$ \\
\hline Argentina & 15 (a) & $19 \mathrm{~h}$ & 3,110 & 4,553 & $>100: 1$ \\
\hline Poland & 15 (a) & $40 \mathrm{~h}$ & 420 & 299 & $28: 1$ \\
\hline Chile & $7(\mathrm{j})$ & 7 & 12,249 & 13,726 & $>100: 1$ \\
\hline Thailand & 4 & 4 & 721 & 380 & $>100: 1$ \\
\hline Colombia & $1.5(\mathrm{~d})$ & 1 & 1,147 & 1,762 & $>100: 1$ \\
\hline Armenia & NA & NA & $\mathrm{x} / \mathrm{NA}$ & $\mathrm{x} / \mathrm{NA}$ & -- \\
\hline Costa Rica & $\mathrm{x}$ & $\mathrm{x}$ & 208 (a) & $226(\mathrm{~h})$ & $>100: 1$ \\
\hline Croatia & $\mathrm{X}$ & $\mathrm{X}$ & $\mathrm{x} / \mathrm{NA}$ & $\mathrm{x} / \mathrm{NA}$ & -- \\
\hline Czech Republic & $\mathrm{X}$ & $\mathrm{X}$ & $271 \mathrm{f}$ & 271 (f) & $>100: 1$ \\
\hline Ecuador & $\mathrm{X}$ & $\mathrm{x}$ & 29 (a) & $4(\mathrm{~h})$ & $>29: 1$ \\
\hline Egypt & $\mathrm{X}$ & $\mathrm{X}$ & 439 (a) & 490 (h) & $>100: 1$ \\
\hline Hungary & $\mathrm{X}$ & $\mathrm{X}$ & 12,929 & 13,692 & $>100: 1$ \\
\hline Jordan & NA & NA & $\mathrm{x} / \mathrm{NA}$ & $\mathrm{x} / \mathrm{NA}$ & -- \\
\hline Latvia & NA & NA & $\mathrm{X}$ & $\mathrm{x}$ & -- \\
\hline Lebanon & $\mathrm{x} / \mathrm{NA}$ & $\mathrm{x} / \mathrm{NA}$ & $\mathrm{X}$ & $\mathrm{x}$ & -- \\
\hline Peru & $\mathrm{x} / \mathrm{NA}$ & $\mathrm{x} / \mathrm{NA}$ & 5,895 & 6,908 & $>100: 1$ \\
\hline
\end{tabular}

${ }^{174}$ Compiled by author from Statistics Canada, Table 376-0051: Foreign Direct Investment (Stocks) in Canada and Canadian Direct Investment Abroad (Stocks) (May 2013). x denotes that confidential data is withheld (typically because the disclosure of limited amounts of FDI to protect the privacy of specific owners); NA denotes data not available. Annual averages (medians) were calculated by the author and rounded to nearest million. The notes indicate partial coverage where five-year data was unavailable for a country, as follows: (a) 2008-10 only, (b) 2008-09 only, (c) 2008-11 only, (d) 2008-10 and 2012 only, (e) 2008 and 2011-12 only, (f) 2008 only, (g) 2009 only, (h) 2010 only, (i) 2011 only, (j) 2012 only. 
DRAFT/ Accepted for publication: Canadian Yearbook of International Law/ Annuaire Canadien de droit international (2014)

\begin{tabular}{|c|c|c|c|c|c|}
\hline Philippines & $\mathrm{X}$ & $\mathrm{X}$ & $454(\mathrm{a})$ & $761 \mathrm{~h}$ & $>100: 1$ \\
\hline Romania & $\mathrm{X}$ & $\mathrm{X}$ & 297 & 348 & $>100: 1$ \\
\hline Slovak Republic & $\mathrm{x} / \mathrm{NA}$ & $\mathrm{x} / \mathrm{NA}$ & $\mathrm{x}$ & $\mathrm{x}$ & -- \\
\hline Tanzania & $\mathrm{x} / \mathrm{NA}$ & $\mathrm{x} / \mathrm{NA}$ & $\mathrm{x}$ & $\mathrm{x}$ & -- \\
\hline Trinidad and Tobago & $\mathrm{x}$ & $\mathrm{X}$ & 1,113 & 893 & $>100: 1$ \\
\hline Ukraine & $\mathrm{x} / \mathrm{NA}$ & $\mathrm{x} / \mathrm{NA}$ & $\mathrm{x}$ & $\mathrm{x}$ & -- \\
\hline Uruguay & $\mathrm{x}$ & $\mathrm{X}$ & 692 (e) & 999 & $>100: 1$ \\
\hline Venezuela & $\mathrm{X}$ & $\mathrm{X}$ & 942 & 898 & $>100: 1$ \\
\hline
\end{tabular}

The data in Table 2 demonstrates that the China FIPPA would apply to far more FDI (\$10.7 billion on average during 2008-12) than any of Canada's relevant treaties other than NAFTA. Thus, while other treaties concluded by Canada may create a significant risk of ISA claims by Canadian investors against another state, they do not raise a direct ${ }^{175}$ risk of ISA claims against Canada. In this respect, the China FIPPA would entail a significant expansion of ISA coverage of foreign-owned assets in Canada. As an aside, if the federal government were to conclude the proposed Canada-EU trade agreement and the U.S.-led Trans-Pacific Partnership Agreement in addition to the China FIPPA, then the great majority of inward FDI in Canada would be covered by ISA. ${ }^{176}$

The data in Table 2 also shows that the China FIPPA would apply to significant amounts of Canadian FDI in China (\$3.7 billion on average during 2008-12). The additional legal protection of those assets based especially on ISA is presumably a key rationale for the federal government's negotiation of the FIPPA, even if the FIPPA leaves gaps, relative to other treaties, in the extent of ISA protection that it provides for Canadian investors by allowing China to continue to bar market access and to maintain an array of discriminatory measures. Yet in principle the availability of ISA for Canadian investors delivers a significant benefit to be weighed against costs to Canada.

\footnotetext{
${ }^{175}$ There is also an indirect risk of claims based on forum-shopping although none appear to have materialized in Canada's case.

176 That is, based on inward FDI stocks in 2013, Canada will have allowed approximately 83\% of its foreign-owned economy to be covered by ISA. Other major countries, including the U.S., Western European states, Australia, and Japan, have not consented to ISA in treaties with each other. In contrast, Canada would have consented to ISA in treaties with all the main capital-exporters: the U.S. in NAFTA and the TPP; the U.K., Germany, France, Netherlands, and Belgium-Luxembourg in the Canada-EU CETA; Japan in the TPP; and China in the China FIPPA.
} 
One common approach to weighing relative costs and benefits of any BIT is by comparing the relative amounts of foreign-owned assets between the states parties. By this measure, the overall costs of the China FIPPA for Canada exceed the overall benefits for Canadian investors on the basis that, during 2008-2013, Chinese investment in Canada exceeded Canadian investment in China by a ratio of about 3 to 1 . Put differently, Canada occupies the capital-importing position under the FIPPA and as a result has accepted more fiscal risk and regulatory constraint associated with ISA. ${ }^{177}$

Also, going forward, there are tentative reasons to expect a greater increase in Chinese investment in Canada than vice versa. Chinese FDI stocks in Canada increased from an annual average of \$334 million (during 2001-05) to \$10.7 billion (during 2008-2012). If one extrapolated this rate of growth, then Chinese FDI stocks would reach an annual average of \$343 billion in 2015-19 and, a few years later, would exceed U.S. FDI stocks in Canada, extrapolated on the basis. This would be approximately 25\% into the minimum lifespan of the China FIPPA assuming that it entered into force in 2014. By comparison, Canadian investment would have reached an average of \$13 billion during 2015-2019 and, in that same period, would be exceeded by Chinese FDI stocks in Canada by a ratio of about 26 to 1 .

This projection of disproportionate growth in Chinese investment in Canada is based on limited data. The projection is supported by public statements by Canadian officials seeking greater Chinese investment in Canada (especially the oil sands), ${ }^{178}$ by the federal government's evident willingness not to insist on market access by Canadian investors in the FIPPA, and by the federal government's statement in 2012 that China’s total global FDI outflows are forecast by some experts to reach \$1 trillion by 2020 compared to \$64

\footnotetext{
${ }^{177}$ Andrew T. Guzman, “Why LDCs Sign Treaties That Hurt Them: Explaining the Popularity of Bilateral Investment Treaties” (1998) 38 Virg J Int'l L 639.

178 e.g. “Oil sands need China, Oliver says on visit” National Post (13 February 2012).
} 
billion in 2011. ${ }^{179}$ On the other hand, the projection is contradicted by the federal government's statement in late 2012 that Chinese state-owned enterprises would in future face limits in acquiring control of Canadian companies in the oil sands and potentially elsewhere in the Canadian economy ${ }^{180}$ and by media reports of a drop-off in Chinese investment in Canada in $2013 .{ }^{181}$ Overall, the projection should be approached with caution.

Another way of thinking about a treaty that provides for ISA is to liken it to a subsidy mechanism in which the host state insures the relevant foreign investors, via new substantive protections and access to ISA in addition to the domestic judicial system, against risks arising from the investors' activities in the host state. ${ }^{182}$ The subsidy to foreign investors is financial because the host state assumes the potential cost of ISA litigation and awards. The subsidy also has administrative and political implications because the host state, in the face of the potential liability, presumably will vet or alter some decisions, with knock-on implications for other actors, as a feature of the new protections for foreign investors. To illustrate, in Canada, the China FIPA would appear to require expanded vetting of

\footnotetext{
${ }^{179}$ Department of Foreign Affairs and International Trade (DFAIT), Responses to Questions submitted through the Chair of the House of Commons Standing Committee on International Trade on behalf of the Liberal Party (Ottawa: undated, received by author 9 November 2012), on file with author.

${ }^{180}$ Prime Minister of Canada, Statement by the Prime Minister of Canada on Foreign Investment (Ottawa: 7 December 2012), available online: http://www.pm.gc.ca/eng/news/2012/12/07/statement-prime-minister-canada-foreign-investment (last accessed 28 January 2014) (“In light of growing trends, and following the decisions made today, the Government of Canada has determined that foreign state control of oil sands development has reached the point at which further such foreign control would not be of net benefit to Canada. Therefore, going forward, the Minister will find the acquisition of control of a Canadian oil-sands business by a foreign state-owned enterprise to be of net benefit only in an exceptional circumstance.")

${ }^{181}$ Nathan Vanderklippe, “Investment deal with China coming ‘in short order’: Baird” The Globe and Mail (16 October 2013).

${ }^{182}$ Emma Aisbett, Larry Karp, and Carol McAusland, "Compensation for Indirect Expropriation in International Investment Agreements:

Implications of National Treatment and Rights to Invest” (2010) 1:2 J Globalization and Development (Article No 6) at 5.
} 
decisions through the federal government's Regulatory Impact Assessment program, which requires regulatory proposals to be assessed for compliance with Canada's investment obligations, stating for example: ${ }^{183}$

Departments and agencies are expected to demonstrate in regulatory impact analysis statements, when relevant, that their proposals do in fact meet Canada’s international trade and other obligations....

Is the proposed regulation a legitimate exercise of governmental regulatory power? Could it constitute expropriation?

[Footnote:] Canada's international trade and investment treaties typically contain a provision prohibiting the nationalization or expropriation of an investment of an investor from another party to that agreement, except where certain conditions have been met, including the payment of compensation.... [G]iven that expropriation can be very fact-specific, in situations where a proposed regulation has the potential to substantially interfere with the operations of an investment in Canada, the regulatory body proposing such a regulation should seek legal advice from the Trade Law Bureau to ensure compliance with Canada's international obligations.

Although it is difficult to evaluate these vetting processes from outside government, it is reasonable to expect that they involve some expenditure of public resources and that they lead in some cases to changes in government decisions that will affect other actors beyond the relevant foreign investor.

\footnotetext{
${ }^{183}$ Treasury Board of Canada Secretariat, Guidelines on International Regulatory Obligations and Cooperation (Ottawa: Queen’s Printer, 2007), available online: http://www.tbs-sct.gc.ca/rtrap-parfa/iroc-cori/iroc-cori01-eng.asp\#Toc175098395 (last accessed 27 January 2014) [emphasis added].
} 
Of course, other factors besides FDI flows - as a rough measure of the quasi-subsidy offered by the state parties to each other's investors - may affect the relative costs and benefits of a FIPPA. For instance, it might be said that Canada is more or less likely than China to avoid fiscal risks associated with ISA or that Canada is more or less likely to change government decisions due to fiscal or symbolic incentives created by ISA. Along these lines, it has been argued that, because Canada provides a more predictable and rulesbased economic environment, Chinese investors are less likely than Canadian investors to benefit from the China FIPPA. ${ }^{184}$ Yet, based on publicly-available information, Canada has faced over 30 ISA claims under NAFTA - of which about half progressed to a fully-constituted arbitration or a known settlement - whereas China has faced one minor ISA claim despite having concluded more than 100 BITs including about 12 muscular BITs with significant capital-exporters. ${ }^{185}$ Further, it appears relevant that aspects of the FIPPA - including China's ability to discriminate against and potentially punish Canadian investors via its right to continue with existing discriminatory measures - may reduce the FIPPA's value for Canadian investors that experience conflict with the Chinese government. $^{186}$

For these reasons, relative FDI stocks between Canada and China offer a useful albeit approximate gauge of the FIPPA's relative costs and benefits, especially because other potential factors are difficult to quantify and do not appear obviously to favour either state party. On this measure, the FIPPA favours China by a substantial margin. Most importantly, other than NAFTA, Canada's capital-importing position under the FIPPA would distinguish the China FIPPA from other treaties concluded by Canada. If ratified, the FIPPA would mark an important change from Canada's approach to ISA in that it would be the first time, since the ISA boom began in the late

\footnotetext{
${ }^{184}$ Milos Barutciski and Matthew Kronby, “Investment agreement with China will benefit Canada” The Globe and Mail (2 November 2012).

${ }^{185}$ These include BITs with Belgium-Luxembourg, Finland, France, Germany, India, the Netherlands, Norway, Russia, South Korea, Spain, Sweden, and Switzerland; UNCTAD, "Full List of Bilateral Investment Agreements concluded [by China], 1 June 2013”, available online: UNCTAD http://unctad.org/Sections/dite_pcbb/docs/bits_china.pdf. Other BITs concluded by China with major economies, especially Austria, Australia, Denmark, Italy, Japan, New Zealand, and the United Kingdom, date from the 1980s and would not reflect China's shift towards a more muscular regime of ISA since the early 2000s.

${ }^{186}$ Supra note 108 and surrounding discussion.
} 
1990s, in which the federal government has consented to a treaty that carries a significant and unequal risk of ISA claims against Canada.

\section{Conclusion}

The analysis in this article focused on the China FIPPA's novelty and non-reciprocity. The FIPPA was evaluated in these respects with reference to its provisions on market access and investment screening; post-establishment national treatment; MFN treatment; performance requirements; ISA transparency; and duration. The text-based study was followed by a discussion of the FIPPA's wider significance given Canada's capital-importing position in relation to China. Criticisms of the FIPPA were specific to the treaty and did not aim to address wider concerns about ISA or the international investment regime. ${ }^{187}$ They also did not examine a range of broader questions about the FIPPA.

For example, how might the Canada-China investment relationship evolve over the next 16 or 31 years? Is there evidence that the FIPPA will contribute to new investment in Canada or China and that the benefits of new investment will outweigh the FIPPA's costs? How would new investment affect each country's economic, environmental, or social priorities? What may have motivated the federal government to accept the significant elements of non-reciprocity in the FIPPA? ${ }^{188}$ Does the ongoing volatility of ISA call for closer attention of the role of ISA in Canada’s FIPPA program? Is the FIPPA's reliance on ISA unacceptable due to encroachment on democratic choice and judicial independence? Does the experience of ISA under NAFTA and BITs give cause for reassurance or heightened concern?

\footnotetext{
${ }^{187}$ e.g. David Gaukrodger and Kathryn Gordon, “Investor-state dispute settlement: A scoping paper for the investment policy community”, Organization for Economic Co-operation and Development (OECD) Working Paper on International Investment No. 2012/3 (OECD Investment Division, 2012).

${ }^{188}$ Carter, supra note 173 at 216.
} 
These questions have not been addressed in this article or, for that matter, in any public study of the China FIPPA. The questions would become more pressing, albeit in hindsight, if the FIPPA were ratified and Canada faced a major ISA claim by a Chinese investor. On the other hand, despite assumptions to the contrary in the federal government's flawed environmental assessment (EA) of the FIPPA, ${ }^{189}$ Canada might benefit from concluding a non-reciprocal FIPPA if the FIPPA was essential to attract substantial quality investment from China or to open markets incidentally for Canadian exports. Due to many outstanding questions, as well as its novelty, significance, and long-term irreversibility, it is suggested that the China FIPPA calls for a thorough, independent, and public review prior to ratification by Canada.

${ }^{189}$ The EA, supra note 134, is of little use as an evaluation of environmental impact and seems more a public relations document. It discounted any environmental impact of the China FIPA on the assumption that there was no direct causative relationship between the FIPA and increased investment flows ("As new flows of investment from China into Canada (or Canada into China) cannot be directly attributed to the presence of a FIPA, there can be no causal relationship found between the implementation of such a treaty and environmental impacts in Canada. It is for this reason that the claim made in the initial EA, that no significant environmental impacts are expected based on the introduction of a Canada-China FIPA, is upheld."). The absence of a causative relationship in this respect was assumed in the EA based partly on the assertion that "this type of government-to-government treaty cannot directly facilitate new investments or directly create new opportunities for investment”. This assertion is inaccurate in that many BITs including FIPAs provide for a right of market access by foreign investors. The assertion was also contradicted by the Prime Minister's Office's in a statement on the China FIPA that was cited but not addressed in this respect in the EA (Prime Minister of Canada, Canada-China Foreign Investment Promotion and Protection Agreement (FIPA) (Ottawa: 8 February 2012), available online:

http://www.pm.gc.ca/eng/news/2012/02/08/canada-china-foreign-investment-promotion-and-protection-agreement-fipa (last accessed 27 January 2014) ("Once implemented, the Canada-China FIPA will facilitate investment flows, contributing to job creation and economic growth in

Canada”. Finally, the EA's discounting of environmental impacts of the China FIPPA is undermined seriously by the EA's failure to consider how a BIT may have environmental impacts due to new legal rights it bestows on foreign investors - whether or not their investment decisions were linked to the FIPA - and the corresponding fiscal risks and regulatory constraints for host states. 


\section{Annex I: Data on limiting language, exceptions, reservations, and disclosure provisions in} Canada's treaties that provide for ISA

\begin{tabular}{|c|c|c|c|c|c|c|c|c|c|}
\hline Treaty & $\begin{array}{l}\text { Year of } \\
\text { entry } \\
\text { into } \\
\text { force }\end{array}$ & $\begin{array}{l}\text { Limiting } \\
\text { language on } \\
\text { fair and } \\
\text { equitable } \\
\text { treatment }\end{array}$ & $\begin{array}{l}\text { Limiting } \\
\text { language on } \\
\text { expropriation }\end{array}$ & $\begin{array}{l}\text { General } \\
\text { exception for } \\
\text { health/ } \\
\text { environmental } \\
\text { / conservation } \\
\text { measures }\end{array}$ & $\begin{array}{l}\text { Financial } \\
\text { stability } \\
\text { exception }\end{array}$ & $\begin{array}{l}\text { Prohibition on } \\
\text { performance } \\
\text { requirements? }\end{array}$ & $\begin{array}{l}\text { Aboriginal } \\
\text { reservation } \\
\text { for } \\
\text { prohibition on } \\
\text { performance } \\
\text { requirements? }\end{array}$ & $\begin{array}{l}\text { Reservation } \\
\text { for } \\
\text { disadvantaged } \\
\text { minorities for } \\
\text { prohibition on } \\
\text { performance } \\
\text { requirements? }\end{array}$ & $\begin{array}{l}\text { Presumptive } \\
\text { disclosure of } \\
\text { ISA } \\
\text { documents? }\end{array}$ \\
\hline Model FIPPA & NA & Yes & Yes & Yes & Yes & Yes & Yes (c) & Yes (c) & Yes \\
\hline $\begin{array}{l}\text { Argentina } \\
\text { FIPPA }\end{array}$ & 1993 & No & No & No & No & No & NA & NA & No \\
\hline Armenia FIPPA & 1999 & No & No & Yes & Yes & Yes & Yes & No & No \\
\hline Barbados FIPPA & 1997 & No & No & Yes & Yes & Yes & Yes & No & No \\
\hline Chile FTA & 1997 & No & No & Yes (a) & No (b) & Yes & Yes & Yes & No \\
\hline Colombia FTA & 2011 & Yes & Yes & Yes & Yes & Yes & Yes & Yes & Yes \\
\hline Panama FTA & 2013 & Yes & Yes & Yes & Yes & Yes & Yes & Yes & Yes \\
\hline Peru FTA & 2009 & Yes & Yes & Yes & Yes & Yes & Yes & Yes & Yes \\
\hline China FIPPA & NA & Yes & Yes & Yes & No & Yes & No & No & No \\
\hline $\begin{array}{l}\text { Costa Rica } \\
\text { FIPPA }\end{array}$ & 1999 & No & No & Yes & Yes & Yes & Yes & No & No \\
\hline Croatia FIPPA & 2001 & No & No & Yes & Yes & Yes & Yes & No & $\mathrm{No}$ \\
\hline $\begin{array}{l}\text { Czech Republic } \\
\text { FIPPA }\end{array}$ & 2012 & Yes & Yes & Yes & Yes & No & NA & NA & Yes \\
\hline Ecuador FIPPA & 1997 & No & No & Yes & Yes & Yes & Yes & No & $\mathrm{No}$ \\
\hline Egypt FIPPA & 1997 & No & No & Yes & Yes & Yes & Yes & No & No \\
\hline Hungary FIPPA & 1993 & No & No & No & No & No & NA & NA & $\mathrm{No}$ \\
\hline Jordan FIPPA & 2009 & Yes & Yes & Yes & Yes & Yes & Yes & Yes & Yes \\
\hline Latvia FIPPA & 2011 & Yes & Yes & Yes & Yes & Yes & Yes & No & Yes \\
\hline Lebanon FIPPA & 1999 & No & No & Yes & Yes & Yes & Yes & No & $\mathrm{No}$ \\
\hline NAFTA & 1994 & Yes & No & Yes (a) & Yes & Yes & Yes & Yes & Yes \\
\hline Panama FIPPA & 1998 & No & No & Yes & Yes & Yes & Yes & No & No \\
\hline Peru FIPPA & 2007 & Yes & Yes & Yes & Yes & Yes & Yes & Yes & Yes \\
\hline $\begin{array}{l}\text { Philippines } \\
\text { FIPPA }\end{array}$ & 1996 & No & No & Yes & Yes & Yes & Yes & No & No \\
\hline Poland FIPPA & 1990 & No & No & No & No & No & NA & NA & $\mathrm{No}$ \\
\hline Romania FIPPA & 2011 & Yes & Yes & Yes & Yes & Yes & Yes & No & Yes \\
\hline Russia FIPPA & 1991 & No & No & No & No & No & NA & NA & No \\
\hline $\begin{array}{l}\text { Slovak Republic } \\
\text { FIPPA }\end{array}$ & 2012 & Yes & Yes & Yes & Yes & No & NA & NA & Yes \\
\hline Tanzania FIPPA & 2013 & Yes & Yes & Yes & Yes & Yes & Yes & Yes & Yes \\
\hline
\end{tabular}


DRAFT/ Accepted for publication: Canadian Yearbook of International Law/ Annuaire Canadien de droit international (2014)

\begin{tabular}{|l|r|r|r|r|r|r|r|r|}
\hline Thailand FIPPA & 1998 & No & No & Yes & Yes & Yes & No \\
\hline $\begin{array}{l}\text { Trinidad and } \\
\text { Tobago FIPPA }\end{array}$ & 1996 & No & No & Yes & Yes & Yes & Yes & \\
\hline Ukraine FIPPA & 1995 & No & No & Yes & Yes & Yes & Yes & No \\
\hline Uruguay FIPPA & 1999 & No & No & Yes & Yes & Yes & No \\
\hline $\begin{array}{l}\text { Venezuela } \\
\text { FIPPA }\end{array}$ & 1998 & No & No & Yes & Yes & Yes & No \\
\hline
\end{tabular}

\section{Annex II: Data on denial of benefits and market access provisions in Canada's treaties that provide for ISA}

\begin{tabular}{|c|c|c|c|c|c|c|c|c|c|}
\hline Treaty & $\begin{array}{l}\text { Year of } \\
\text { entry } \\
\text { into } \\
\text { force }\end{array}$ & $\begin{array}{l}\text { Denial of } \\
\text { benefits clause }\end{array}$ & $\begin{array}{l}\text { Denial of } \\
\text { benefits clause } \\
\text { with express } \\
\text { allowance to } \\
\text { deny after } \\
\text { claim }\end{array}$ & $\begin{array}{l}\text { Market access } \\
\text { based on pre- } \\
\text { establishment } \\
\text { national } \\
\text { treatment } \\
\text { (pre-E NT) }\end{array}$ & $\begin{array}{l}\text { Exemption of } \\
\text { pre-E NT } \\
\text { obligation } \\
\text { from ISA or } \\
\text { exemption of } \\
\text { Investment } \\
\text { Canada Act } \\
\text { from ISA/ } \\
\text { pre-E NT }\end{array}$ & $\begin{array}{l}\text { Exemption of } \\
\text { existing non- } \\
\text { confirming } \\
\text { measures } \\
\text { from post- } \\
\text { establishment } \\
\text { NT }\end{array}$ & $\begin{array}{l}\text { Market access } \\
\text { based on pre- } \\
\text { establishment } \\
\text { MFN } \\
\text { treatment } \\
\text { (pre-E MFN) }\end{array}$ & $\begin{array}{l}\text { Exemption of } \\
\text { pre-E MFN } \\
\text { from ISA or } \\
\text { exemption of } \\
\text { Investment } \\
\text { Canada Act } \\
\text { from ISA/ } \\
\text { pre-E MFN }\end{array}$ & $\begin{array}{l}\text { Express } \\
\text { application of } \\
\text { MFN } \\
\text { treatment to } \\
\text { past treaties }\end{array}$ \\
\hline Model FIPPA & NA & Yes & No & Yes & Yes & Yes (d) & Yes & Yes & No (g) \\
\hline $\begin{array}{l}\text { Argentina } \\
\text { FIPPA }\end{array}$ & 1993 & No & NA & No & NA & Yes & No & NA & No \\
\hline Armenia FIPPA & 1999 & No & NA & No & NA & Yes & No & NA & No \\
\hline Barbados FIPPA & 1997 & No & NA & No & NA & Yes & No & NA & No \\
\hline Chile FTA & 1997 & Yes & No & Yes & No & Yes (e) & Yes & Yes & No (g) \\
\hline Colombia FTA & 2011 & Yes & No & Yes & Yes & Yes (e) & Yes & Yes & No \\
\hline Panama FTA & 2013 & Yes & No & Yes & Yes & Yes (d) & Yes & Yes & No \\
\hline Peru FTA & 2009 & Yes & No & Yes & Yes & Yes (d) & Yes & Yes & No \\
\hline China FIPPA & NA & Yes & Yes & No & NA & Yes & Yes & Yes & Yes \\
\hline $\begin{array}{l}\text { Costa Rica } \\
\text { FIPPA }\end{array}$ & 1999 & Yes & No & Yes & Yes & Yes & Yes & Yes & No \\
\hline Croatia FIPPA & 2001 & No & NA & Yes & Yes & Yes & Yes & Yes & No \\
\hline $\begin{array}{l}\text { Czech Republic } \\
\text { FIPPA }\end{array}$ & 2012 & Yes & No & No & NA & Yes & No & NA & No \\
\hline Ecuador FIPPA & 1997 & No & NA & Yes & Yes & Yes & Yes & Yes & No \\
\hline Egypt FIPPA & 1997 & No & NA & Yes & Yes & Yes & Yes & Yes & No \\
\hline Hungary FIPPA & 1993 & No & NA & No & NA & Yes & No & NA & No \\
\hline Jordan FIPPA & 2009 & Yes & No & Yes & Yes & Yes (d) & Yes & Yes & Yes \\
\hline Latvia FIPPA & 2011 & Yes & No & Yes & Yes & Yes & Yes & Yes & No \\
\hline Lebanon FIPPA & 1999 & No & NA & Yes & Yes & Yes & Yes & Yes & No \\
\hline
\end{tabular}


DRAFT/ Accepted for publication: Canadian Yearbook of International Law/ Annuaire Canadien de droit international (2014)

\begin{tabular}{|c|c|c|c|c|c|c|c|c|c|}
\hline NAFTA & 1994 & Yes & No & Yes & Yes & Yes (d) & Yes & Yes & $\mathrm{No}$ \\
\hline Panama FIPPA & 1998 & No & NA & Yes & Yes & Yes & Yes & Yes & $\mathrm{No}$ \\
\hline Peru FIPPA & 2007 & Yes & No & Yes & Yes & Yes (d) & Yes & Yes & Yes \\
\hline $\begin{array}{l}\text { Philippines } \\
\text { FIPPA }\end{array}$ & 1996 & No & NA & Yes & Yes & Yes & Yes & Yes & No \\
\hline Poland FIPPA & 1990 & No & NA & No & NA & No (f) & No & NA & No \\
\hline Romania FIPPA & 2011 & Yes & No & Yes & Yes & Yes & Yes & Yes & $\mathrm{No}$ \\
\hline Russia FIPPA & 1991 & No & NA & No & NA & Yes & No & NA & No \\
\hline $\begin{array}{l}\text { Slovak Republic } \\
\text { FIPPA }\end{array}$ & 2012 & Yes & No & No & NA & Yes & No & NA & No \\
\hline Tanzania FIPPA & 2013 & Yes & No & Yes & Yes & Yes & Yes & Yes & Yes \\
\hline Thailand FIPPA & 1998 & No & NA & Yes & Yes & Yes & Yes & Yes & $\mathrm{No}$ \\
\hline $\begin{array}{l}\text { Trinidad and } \\
\text { Tobago FIPPA }\end{array}$ & 1996 & No & NA & Yes & Yes & Yes & Yes & Yes & No \\
\hline Ukraine FIPPA & 1995 & No & NA & Yes & Yes & Yes & Yes & Yes & $\mathrm{No}$ \\
\hline Uruguay FIPPA & 1999 & No & NA & Yes & Yes & Yes & Yes & Yes & $\mathrm{No}$ \\
\hline $\begin{array}{l}\text { Venezuela } \\
\text { FIPPA }\end{array}$ & 1998 & No & NA & Yes & Yes & Yes & Yes & Yes & No \\
\hline
\end{tabular}

Note on Annexes I and II: Data collected from texts of all of Canada's foreign investment promotion protection agreements (FIPPAs) and free trade agreements (FTAs) that provide for investor-state arbitration (ISA) that were in force as of 27 January 2013 . The relevant treaty texts are available online: http://www.international.gc.ca/trade-agreements-accords-commerciaux/agr-acc/fipaapie/index.aspx?lang=eng (last accessed 27 January 2014). "NA" means not applicable. (a) denotes that general exceptions are limited to certain performance requirements only. (b) denotes that the treaty excludes related investments such as in financial institutions, loans, etc. (c) denotes that the treaty allows for annexes that in other FIPPAs include the relevant reservation. (d) denotes negative-list requirement for exempted national measures. (e) denotes negative-list requirement for exempted national and state/ provincial measures. (f) denotes that the treaty does not provide for post-establishment national treatment. (g) denotes express application of MFN treatment to future treaties only. 